PRZEGLĄD NAUK HISTORYCZNYCH 2018, R. XVII, NR 2

http://dx.doi.org/10.18778/1644-857X.17.02.02

\title{
Królewska krew. Polscy potomkowie Zygmunta Starego i Katarzyny Telniczanki w czasach staropolskich
}

Streszczenie. Przedmiotem badań podjętych przez Autora jest zbiorowość polskich potomków Reginy, starszej z dwóch córek króla Zygmunta I Starego i jego długoletniej kochanki - Katarzyny Telniczanki. Do tej pory przyjmowano, że ostatnimi potomkami króla byli żyjący w pierwszej połowie XVII w. jego praprawnukowie - Władysław i Krystyna z Białaczowa Straszowie. Dzięki odnalezionym przez Autora dokumentom udało się jednak ustalić, że matka wspomnianych Władysława i Krystyny Straszów - Urszula z Krezów Straszowa miała siostrę - Zofię, która poślubiła Baltazara Lutomirskiego. Od jej córki, Zofii z Lutomirskich $1^{\circ} \mathrm{v}$. Trembińskiej (Trębińskiej) $2^{\circ}$ v. Szamowskiej pochodzą wszyscy, tak historyczni, jak i żyjący do dziś potomkowie Zygmunta Starego i Katarzyny Telniczanki. W artykule przedstawiono listę wszystkich descendentów króla żyjących od początku XVI do przełomu XVIII i XIX w. W sumie było to 114 osób (58 mężczyzn i 56 kobiet). Zwraca uwagę to, że do końca pierwszej ćwierci XVII w. potomkowie Zygmunta I i Katarzyny Telniczanki wyznawali kalwinizm. W całym badanym okresie byli to niemal wyłącznie przedstawiciele zamożnej i średniej szlachty. Nie było wśród nich senatorów, a tylko nieliczni pełnili urzędy ziemskie. Autor zwraca też uwage na to, że sporządzona przez niego lista potomków przedostatniego Jagiellona na polskim tronie nie jest bynajmniej zamknięta. W kilku przypadkach nie udało się bowiem znaleźć źródłowego potwierdzenia na to, czy wspomniana w artykule para małżeńska miała dzieci. Wiele razy Autor musiał zatem poprzestać na stwierdzeniu, że dalsze losy jakiejś osoby sa mu nieznane. Otwiera to przed następnymi badaczami szansę na znaczące uzupełnienie jego ustaleń.

Słowa kluczowe: Zygmunt I Stary, Katarzyna Telniczanka, genealogia, potomkowie nieślubnych córek Zygmunta Starego w XVI-XVIII w.

* Wydział Filozoficzno-Historyczny, Instytut Historii, Katedra Historii Nowożytnej, e-mail: zanusik@uni.lodz.pl. 
$\mathrm{O}$ d czasu transformacji ustrojowej w 1989 r. można w Polsce zaobserwować ogromny wzrost zainteresowania badaniami genealogicznymi. Podejmowane sa również próby opracowania drzewa potomków Wacława II ks. raciborskiego, przedstawiciela bocznej linii panującego w Czechach rodu Przemyślidów, a co za tym idzie, stworzenia pełnej bazy rodzin i osób mających wśród swoich przodków przedstawicieli dynastii panujacych ${ }^{1}$. Wśród pojawiających się na rynku wydawniczym opracowań poświęconych kwestiom natury genealogicznej brakuje jednak pracy, której bohaterami byliby potomkowie nieślubnych córek panującego w Polsce w latach 1506-1548 króla Zygmunta I Starego. W opracowaniu tym postaram się wypełnić tę lukę.

Zacznijmy zatem od przypomnienia znanych już ustaleń. Zygmunt, piąty syn Kazimierza Jagiellończyka i Elżbiety Rakuszanki, urodził się 1 stycznia 1467 r. w Kozienicach. Dnia 27 listopada 1499 r. jego najstarszy brat - Władysław, król węgierski i czeski, nadał mu w lenno księstwo głogowskie, a w 1501 r. również opawskie. W 1504 r. ustanowił go z kolei namiestnikiem Łużyc. Wszystkie te posiadłości dzierżył Zygmunt do śmierci brata Aleksandra. W dniu 20 października 1506 r. został wyniesiony na Wielkie Księstwo Litewskie, a 8 grudnia tego samego roku na sejmie piotrkowskim został wybrany na tron polski. Jego koronacja odbyła się w Krakowie 24 stycznia 1507 r. Zmarł w tym samym mieście 1 kwietnia 1548 r. $^{2}$ Zapewne na początku 1498 r., czyli jeszcze przed objęciem księstwa głogowskiego, Zygmunt związał się z kobieta, która przez długie lata była towarzyszką jego życia. Mowa tu o Katarzynie Ochstat, zwanej Telniczanką. Urodziła się ona około 1480 r., być może właśnie we wsi Telnice, niedaleko Brna na Morawach. O jej rodzicach nic nie wiadomo, ale przyjmuje się, że pochodziła $z$ rodziny mieszczańskiej (miała siostrę Małgorzatę,

${ }^{1}$ Por. zwłaszcza R.T. Prinke, A. Sikorski, Polscy potomkowie Piastów i innych dynastii panujacych, Poznań 1997; oraz S. Szy b kow ski, Zwiazki rodzinne Danaborskich z elita urzędnicza Kujaw i ziemi dobrzyńskiej, „Roczniki Historyczne" 2000, R. LXIV, s. 157-168. W przywołanym tu artykule wyraźnie wykazano, że Febronia $z$ Danaborskich, żona Mikołaja Działyńskiego, była córką Włodka z Danaborza i jego pierwszej żony, Witochy z Pakości i Krotoszyna. Jej dzieci nie moga być zatem uznane za potomków Wacława II ks. raciborskiego, co sugerowali w swojej książce R.T. Prinke i A. Sikorski.

${ }^{2}$ Por. Z. W dow is zew ski, Genealogia Jagiellonów i Domu Wazów w Polsce, Kraków 2005, s. 115-117; U. B orkow s ka, Dynastia Jagiellonów w Polsce, Warszawa 2011, s. 518-522. 
zamężną $z$ mieszczaninem ołomunieckim Leonardem Hohesteigerem). Od 1498 r. stale towarzyszyła Zygmuntowi, a po objęciu przez niego tronu polskiego osiadła w Krakowie. Jej zwiazek z królem trwał do $1509 \mathrm{r}$. W związku $z$ własnymi planami matrymonialnymi Zygmunt zdecydował się bowiem w końcu tego roku wydać swoja długoletnia kochankę za Andrzeja Kościeleckiego (ok. 1455-1515), podskarbiego wielkiego koronnego. Małżeństwo to wywołało oburzenie zarówno wśród członków rodziny Kościeleckich, jak i wśród senatorów. Król dbał o zabezpieczenie materialne Katarzyny. Jeszcze w 1510 r. przyznał jej pensję 100 dukatów rocznie pobieranych od Żydów krakowskich. Dnia 21 listopada 1515 r., zatem już po śmierci Kościeleckiego, który zmarł 6 września tego roku, nadał jej $z$ kolei w dożywocie miasteczko Słomniki i wieś Rakowice pod Krakowem, a w roku 1517 potwierdził prawo do posiadania domu przy ulicy Grodzkiej w Krakowie. Gdy w 1519 r. naturalny syn króla i Katarzyny, Jan z Książąt Litewskich został biskupem wileńskim, matka udała się $z$ nim do Wilna i osiadła na stałe w tym mieście. Wywierała duży wpływ na syna i bezceremonialnie mieszała się do zarządzania diecezją. Prowadziła też swobodny tryb życia, uczestniczacc w zabawach i trudniąc się znachorstwem oraz "czarami”. Być może jej postępowanie przyczyniło się do tego, że Litwini rozpoczęli starania o przeniesienie Jana na jedno $z$ biskupstw koronnych. Ostatecznie Katarzyna pozostała jednak $z$ synem w Wilnie, gdzie zmarła między 25 sierpnia a 10 września 1528 r. Zwłoki jej przewieziono do Krakowa, a 11 grudnia pochowano w kościele na Kleparzu. Ze związku z królem Zygmuntem Katarzyna pozostawiła syna Jana oraz córki Reginę i Katarzynę ${ }^{3}$ Z Andrzejem Kościeleckim miała nieznanego $z$ imienia syna, który zmarł przed ojcem, oraz pogrobową córkę Beatę (1515-1576), wydaną w 1538 r. za księcia Ilię Ostrogskiego (ok. 1510-1539). Z tego związku urodziła się słynna i nieszczęśliwa Halszka $z$ Ostroga (1539-1582). W roku 1564, mając 49 lat, Beata $z$ Kościeleckich Ostrogska wyszła po raz drugi za maż za znacznie od siebie młodszego wojewodę sieradzkiego Olbrachta Łaskiego (1536-1605). Jej drugie małżeństwo było bezdzietne ${ }^{4}$.

${ }^{3}$ Por. A. Swieżawski, Kościelecka (z Kościelca) Katarzyna, [w:] Polski słownik biograficzny [dalej: PSB], t. XIV, Wrocław-Warszawa-Kraków 1968-1969, s. 397-398; Z. W dowiszewski, op. cit., s. 182-186; U. Borkowska, op. cit., s. 561.

${ }^{4}$ Por. A. Swieżawski, Kościelecki (z Kościelca) Andrzej, [w:] PSB, t. XIV, s. 398-400; T. Kempa, Dzieje rodu Ostrogskich, Toruń 2003, s. 53-78; R. Że- 
Najstarszym dzieckiem Zygmunta i Katarzyny był syn Jan (Janusz). Urodził się on 8 stycznia 1499 r. w Krakowie. Od wczesnego dzieciństwa był przeznaczony do stanu duchownego. Początkowo nazywano go Janem de Thelnicz (Ochstat de Thelnicz). Pod takim nazwiskiem uzyskał w $1510 \mathrm{r}$. nominację na jedna $z$ kanonii katedry krakowskiej. W tym samym roku król zwrócił się do papieża $z$ prośba o usunięcie przeszkód kanonicznych super defectu natalium. Papież Juliusz II bullą datowaną w Rzymie 29 lipca 1510 r. udzielił Janowi dyspensy od przeszkód wynikających $z$ jego urodzenia, legitymował go i nobilitował. W 1512 r., na żądanie króla, Jan uzyskał zatwierdzenie na prepozytury w kapitułach poznańskiej i płockiej. W tym samym roku Zygmunt nadał synowi nazwisko z Ksiąząt Litewskich (ex ducibus Lithuanie), co miało być podkreśleniem faktu, że nie jest on księciem krwi, a jedynie naturalnym synem królewskim. W latach 1512-1516 Jan przebywał poza granicami kraju. Odbył w tym czasie studia w zakresie prawa rzymskiego i kanonicznego na uniwersytecie w Bolonii. W 1519 r. został biskupem wileńskim $z$ prawem zachowania dochodów $z$ kanonii poznańskiej. Objął rządy w diecezji, nie przyjmując jednak święceń. $Z$ biegiem czasu Jan $z$ Książąt Litewskich w coraz większym stopniu stawał się zastępcą ojca na Litwie. W 1526 r. wysunięto projekt ożenienia go $z$ siostra ostatnich książąt mazowieckich, Anna i nadania mu w lenno Mazowsza. Ostatecznie projekt ten jednak upadł. Jan przez dłuższy czas nie był pewny, czy pozostanie w stanie duchownym. Dopiero w 1531 r. zdecydował się przyjać sakrę biskupią. Bullą z 28 czerwca 1531 r. papież Klemens VII udzielił mu indultu na przyjęcie wyższych święceń kapłańskich i na konsekrację. Niechęć do Jana ze strony wielmożów litewskich (zwłaszcza Gasztołdów i Radziwiłłów) skłoniła go do opuszczenia Wilna. W 1536 r. Zygmunt I przeniósł go na biskupstwo poznańskie. Po formalnym wyborze przez kapitułę (5 maja 1536 r.) Jan zrzekł się prepozytury płockiej, która objął nowy biskup wileński - książę Paweł Holszański. Jan z Książąt Litewskich był świetnym gospodarzem i administratorem dóbr biskupich. Zgromadził też znaczny majątek osobisty, tak w dobrach ziemskich, jak i rucho-

1ews ki, Łaska 1. v. Ostrogska z Kościeleckich Beata, [w:] PSB, t. XVIII, WrocławWarszawa-Kraków 1973, s. 222-224; ide m, Easki Olbracht, [w:] ibidem, s. 246250; i d e m, Ostrogski Ilia (Eliasz), [w:] ibidem, t. XXIV, Wrocław 1979, s. 480-481; i d e m, Górkowa Elżbieta (Halszka z Ostroga), [w:] ibidem, t. VIII, Wrocław-Warszawa-Kraków 1959-1960, s. 424-426. 
mościach. Uroczysty wjazd do Poznania odbył dopiero 24 marca 1537 r. Po niespełna rocznym pobycie w stolicy Wielkopolski zapadł na czterodniową gorączkę, która stała się bezpośrednią przyczyną jego śmierci. Zmarł 18 lutego 1538 r. w Poznaniu. Został pochowany w katedrze wileńskiej. W swoim testamencie część majętności zapisał swojej przyrodniej siostrze Beacie Kościeleckiej. Resztę odziedziczył Zygmunt August. W swojej ostatniej woli całkowicie pominą natomiast rodzoną siostrę Katarzynę i córki drugiej rodzonej siostry - Anny, z którymi toczył spory majątkowe po śmierci matki, Katarzyny z Ochstatów Kościeleckiej w 1528 r. ${ }^{5}$

Katarzyna była trzecim, najmłodszym dzieckiem Zygmunta i Katarzyny Telniczanki. Urodziła się około 1503 r. Od wczesnego dzieciństwa przebywała na węgierskim dworze stryja, Władysława II Jagiellończyka. W 1515 r. przybyła do Wiednia jako jedna z panien towarzyszących królewnie Annie Jagiellonce podczas spotkania cesarza Maksymiliana I z władcami Węgier i Polski. W 1522 r. pojawiły się pogłoski o możliwości wydania jej za mąż za hospodara mołdawskiego Stefana Młodego. Król Zygmunt I był jednak zdecydowanym przeciwnikiem tego związku i nie zezwolił na podjęcie jakichkolwiek rozmów w tej sprawie $z$ dworem w Jassach. Najpewniej w 1524 r. Katarzyna została żona szwabskiego arystokraty Jerzego (Georga) II (III) hr. von Montfort. Ród hrabiów von Montfort, blisko związany $\mathrm{z}$ dworem wiedeńskim, posiadał dobra w Tyrolu, Styrii i Karyntii. Mąż najmłodszej córki Zygmunta Starego i Katarzyny Telniczanki urodził się po 1475 a przed 1480 r. jako syn hrabiego Hermana II i Cecylii von Liechtenstein-Murau. Władał dobrami Peckach, Krems i Monsperg oraz hrabstwami Pfannberg i Tettnang. Miał z Katarzyną czworo dzieci: synów Jana VI, Jakuba I, Hermana IV oraz córkę Krystynę. Zmarł 30 maja 1544 r. Katarzyna przeżyła męża. Umarła przed 9 września roku $1548^{6}$.

${ }^{5}$ Por. A. Swi ė̇aw ski, Jan (Janusz) z Książąt Litewskich, [w:] PSB, t. X, Wrocław-Warszawa-Kraków 1962-1964, s. 439-441; Z. Wdowiszewski, op. cit., s. 186-191; U. Borkowska, op. cit., s. 562-563.

${ }^{6}$ Por. R. Żelewski, Katarzyna (ok. 1503-1548), żona Jerzego II hr. Montfortu, [w:] PSB, t. XII, Wrocław-Warszawa-Kraków 1966-1967, s. 222; Z. W dowis zewski, op. cit., s. 194-197; U. Borkowska, op. cit., s. 564-565; J.N. Vanotti, Geschichte der Grafen von Montfort und von Werdenberg, Belle-Vue, bei Constanz 1845, s. 190; K.H. Burmeister, Graf Georg III. von Montfort-Bregenz-Pfannberg (ca. 1475/80-1544). Eine biographische Skizze, „Monfort. Vierteljährensschrift für Geschichte, Heimat - und Volkskunde (Gegenwart) Vorarlbergs” 2009, Bd. LXI, s. 7-27 (tu jednak na s. 19 błędne przypisanie Jerzemu I Kata- 
Najstarszy z synów Jerzego i Katarzyny - Jan (Johann) VI zmarł w młodym wieku. Drugi z kolei, Jakub (Jakob) I (1530-1573), 9 lutego 1553 r. ożenił się z Katarzyna (Kathrin) von Fugger zu Kirchberg und Weisenhorn (1532-1585), córką hrabiego Antoniego (Antona) i Anny von Rehlinger. Para doczekała się bardzo licznego potomstwa: Jerzego V (ur. 18 X 1554), Jana VIII (ur. 20 IX 1555), Katarzyny (ur. 12 VIII 1556), Sybilli (ur. 14 XII 1558), Zygmunta I (ur. 27 XI 1559), Antoniego I (ur. 24 X 1560), Wolfganga III (ur. 29 XI 1561) i Jakuba II (ur. 18 XII 1562). Spośród tej gromadki dzieci wieku dojrzałego dożyła tylko czwórka - synowie Jerzy (Georg) i Jan (Johann) oraz córki Katarzyna (Katarina) i Sybilla (Sibylla). Najstarszy z rodzeństwa - hrabia Jerzy V (1554-1590) w 1584 r. ożenił się co prawda z czeską arystokratką Anną von Lobkowitz (Lobkovic), ale zmarł bezpotomnie. Jan VIII hrabia von Montfort (1555-1619) w 1587 r. poślubił Sybillę von Fugger, z która miał syna Hugona (Haug), kolejnego hrabiego von Montfort, i córkę Katarzynę. Starsza $z$ córek hrabiego Jakuba I - Katarzyna (1556-1631) wyszła za mąż za czeskiego magnata Adama von Neuhaus (Adam II $z$ Hradce) i urodziła mu sześcioro dzieci, $z$ których wieku dojrzałego dożyła tylko dwójka - syn Joachim Ulryk i córka Łucja Otylia. Młodsza - Sybilla (1558-1600) została wydana za Maurycego Krzysztofa (Moriz Christoph) von Khevenhüller. Jej drugim mężem, poślubionym po śmierci pierwszego, został natomiast w 1597 r. Jan Baptysta (Johann Baptist) von Salamanca hrabia zu Orlenberg. $Z$ pierwszego małżeństwa doczekała się dwójki dzieci - Augustyna i Katarzyny. Herman (Hermann) IV hrabia von Montfort, najmłodszy syn Jerzego II (III) i Katarzyny, ożenił się z Sarą von Schärffenberg. Miał z nią tylko jedną córkę - Annę Marię (zm. 1583), która w 1580 r. wydano za Jerzego Krzysztofa (Georg Christoph) hrabiego von Losenstein. Herman IV zmarł przed 1564 r., a jego żona w 1566 r. Siostra Hermana IV, jedyna córka hrabiego Jerzego II (III) i Katarzyny, Krystyna (1525-1610) w 1544 r. poślubiła Krzysztofa (Christoph) von Losenstein auf Schallaburg (zm. 1558), z którym miała synów Jerzego i Jana Wilhelma ${ }^{7}$. Rzecz jasna wywód potomków najmłodszej córki Zyg-

rzynie jeszcze jednej córki - Franciszki, która w 1536 r. miała zostać wydana za Gerharda von Manderscheid auf Gerolstein).

7 Por. R. Żelewski, Katarzyna..., s. 222; Z. W dowiszewski, op. cit., s. 196; U. Borkowska, op. cit., s. 196; J.N. Vanotti, op. cit., s. 190; K.H. Burmeister, op. cit., s. 18-19; id e m, Montfort, von (Grafen von Montfort), [w:] Neue Deutsche Biographie, Bd. XVIII, Berlin 1997, s. 51-54. 
munta Starego i Katarzyny Telniczanki można by długo kontynuować, dochodząc finalnie aż do jej współcześnie żyjących descendentów. Ponieważ jednak jest to poboczny wątek naszych rozważań, pozwolę sobie zakończyć w tym miejscu swoje dociekania dotyczące tej kwestii.

Regina była drugim dzieckiem i starszą $z$ dwóch córek króla Zygmunta Starego i Katarzyny Telniczanki. Od niej właśnie wywodzą się wszyscy polscy potomkowie jej rodziców. Urodziła się w 1500 lub w 1501 r. Już 18 października 1518 r. została wydana za Hieronima Szafrańca $z$ Pieskowej Skały h. Starykoń. Jej posag w wysokości 6000 florenów, jak również drugą taką sumę tytułem wiana zabezpieczył ojciec jej męża - Stanisław Szafraniec na Pieskowej Skale i innych dobrach. Regina zmarła już 20 maja 1526 r. w Krakowie, a dwa dni później została pochowana w jednym $z$ kościołów na wzgórzu wawelskim. Z małżeństwa $z$ Szafrańcem pozostawiła trzy córki: Katarzynę, Annę i Zuzannę 8 . Mąż Reginy - Hieronim Szafraniec (ok. 1490-1554/1555) był synem kasztelana sacdeckiego Stanisława (zm. 1525) i jego pierwszej żony Zuzanny Buczackiej h. Awdaniec (zm. 1501). Od 1519 r. był z cesji ojca starosta grodowym chęcińskim. W 1537 r. został sekretarzem królewskim i tytuł ten nosił przynajmniej do roku 1554. Brał udział w bitwie pod Obertynem. Był także jednym $z$ pierwszych w Polsce zwolenników reformacji. Dnia 7 sierpnia 1527 r. sumę 6000 florenów, będąca posagiem ich matki, zapisał swoim małoletnim córkom i następnie ja zabezpieczył, za zgoda króla, na tenucie wolbromskiej. Po śmierci Reginy żenił się jeszcze dwukrotnie. W sierpniu 1527 r. poślubił Zofię Zborowską h. Jastrzębiec (zm. 1544), córkę Andrzeja, kasztelana żarnowskiego, siostrzenicę kanclerza Krzysztofa Szydłowieckiego. Przed 20 maja 1549 r. ożenił się natomiast z Anną Wasilińska (Wasilewska), mieszczką z Olkusza. Z drugiego małżeństwa miał córkę Zofię (zm. 1566/1567), od 1546 r. żonę Mikołaja Oleśnickiego $z$ Pińczowa, oraz syna Mikołaja, który zmarł wkrótce po śmierci ojca, przed początkiem listopada 1555 r. Z trzecią żona doczekał się piątki dzieci: synów Piotra i Stanisława oraz córek Barbary, Anny i Konstancji ${ }^{9}$.

8 Por. Z. Wdowiszewski, op. cit., s. 192-193; U. Borkowska, op. cit., s. $563-564$.

${ }^{9}$ Por. A. Biedrzycka, Szafraniec Hieronim (Jarosz) z Pieskowej Skały, [w:] PSB, t. XLVI, Warszawa-Kraków 2009-2010, s. 436-439; Z. W dow is zewski, op. cit., s. 193-194; U. Borkowska, op. cit., s. 564 (tu jednak błędna infor- 
Najmłodsza córka Hieronima Szafrańca i Reginy - Zuzanna zmarła młodo jako panna. Najstarsza - Katarzyna poślubiła Andrzeja Jasieńskiego h. Poraj, syna Ignacego, a po owdowieniu wyszła raz jeszcze za mąż za Remigiana Chełmskiego h. Ostoja (zm. ok. 1575), jednego $z$ przywódców szlachty kalwińskiej w Małopolsce. Data śmierci Katarzyny jest nieznana, ale na pewno żyła ona jeszcze w 1565 r. Z pewnościa zmarła jednak bezpotomnie, a przynajmniej nie pozostawiła dzieci, które żyłyby dłużej niż ona sama. Podana przez Stanisława Szczotkę, autora biogramu Remigiana Chełmskiego w Polskim słowniku biograficznym, informacja, że Chełmski miał nieznanych $z$ imienia dwóch synów, których kształcił za granica, dotyczy raczej jego bratanków. Istnieje jednak również taka możliwość, że obaj ci synowie Remigiana Chełmskiego zmarli przed śmiercia matki, co po zgonie Katarzyny Szafrańcówny zmusiło jej męża do wycofania się $z$ walki o przejęcie klucza włoszczowskiego. Trzecia córka Hieronima Szafrańca i Reginy - Anna (zm. ok. 1557) poślubiła natomiast Mikołaja Krezę $z$ Bobolic h. Przeginia, rotmistrza królewskiego ${ }^{10}$.

O mężu Anny Szafrańcówny, Mikołaju Krezie z Bobolic wiemy stosunkowo niewiele. Był on synem Mikołaja Krezy (zm. 1506), starosty lwowskiego i przemyskiego, pierwszego $z$ tej rodziny właściciela zamku w Bobolicach, oraz jego żony Doroty. Urodził się zapewne około roku 1500, skoro brał udział w przegranej przez wojska polsko-litewskie bitwie pod Sokalem stoczonej 2 sierpnia 1519 r. Tu dostał się do niewoli tatarskiej, w której spędził dwa lata. Później sprzedany do Turcji, spędził tam jako niewolnik kolejnych pięć kwartałów. $Z$ inskrypcji na jego epitafium zamieszczonej w pracy Szymona Starowolskiego pochodzi informacja, że obiecał on swojemu tureckiemu panu, że jeśli zwolni go $z$ niewoli na słowo honoru i pozwoli mu pojechać do domu, w umówionym terminie

macja, że Hieronim Szafraniec żenił się pięciokrotnie, przy czym przypisane mu dwie pierwsze żony były w istocie małżonkami jego ojca).

10 Por. Z. Wdowiszewski, op. cit., s. 192-193; A. Biedrzycka, op. cit., s. 438; S. Szczotka, Chetmski Remigian, [w:] PSB, t. III, Kraków 1937, s. 286; W. Urban, Umiejętność pisania $w$ Małopolsce $w$ drugiej połowie XVI wieku, „Przegląd Historyczny" 1977, t. LXVIII, z. 2, s. 234 (tu informacja, że Remigian Chełmski żył jeszcze w 1575 r.); K. Nies i ecki, Herbarz polski, wyd. J.N. Bobrowicz, t. VIII, Lipsk 1841, s. 506-507 (tu informacja, że Hieronim Szafraniec z żona pochodząca $z$ rodu Kościeleckich [czyli interesująca nas Regina] miał trzy córki - Zuzannę, która zmarła w panieństwie, Katarzynę $1^{\circ}$ v. Jasieńską $2^{\circ}$ v. Chełmską, która nie pozostawiła po sobie żadnego potomstwa, oraz Annę, małżonkę Mikołaja Krezy). 
wróci do niego, przywożąc ze sobą ustaloną kwotę okupu. Kiedy zaś dotrzymał słowa, ucieszony tym faktem Turek, nie tylko zrezygnował $z$ pieniędzy za okup, ale jeszcze podarował mu pięknego rumaka. Po powrocie do kraju Kreza służył w wojsku. Z Szafrańcówną ożenił się prawdopodobnie około 1540 r. W kwietniu 1550 r. wniósł w Krakowie do akt Metryki Koronnej protest przeciwko swojemu teściowi, Hieronimowi Szafrańcowi, który nie dotrzymał terminu przekazania mu zapisanej wcześniej sumy 1200 florenów. Podobnie jak Szafraniec, oraz mężowie dwóch innych jego córek (Katarzyny i Zofii), Mikołaj Kreza był wyznawca kalwinizmu ${ }^{11}$.

Po śmierci starosty chęcińskiego podjął starania - wraz ze swoimi szwagrami Remigianem Chełmskim i Mikołajem Oleśnickim - o przejęcie całego majątku po nim. Rozgrywka toczyła się o opanowanie Pieskowej Skały z przyległościami w powiecie krakowskim, klucza włoszczowskiego w powiecie chęcińskim oraz zastawionej „w starych sumach" na kwotę 6432 florenów tenuty wolbromskiej w powiecie księskim. Już w 1555 r. wszyscy trzej, wspierani przez Stanisława Szafrańca, stryjecznego bratanka zmarłego, rozpoczęli zabiegi zmierzające do unieważnienia trzeciego małżeństwa Hieronima i uznania pochodzacego $z$ niego potomstwa za nieprawe. W tym samym czasie Chełmski, Kreza i Oleśnicki wystapili na drogę sądowa przeciwko opiekunom małoletniego Mikołaja Szafrańca - wojewodzie krakowskiemu Stanisławowi Tęczyńskiemu, podkanclerzemu koronnemu Janowi Przerembskiemu oraz Mikołajowi Secygniowskiemu i Marianowi Przyłęckiemu, którzy po śmierci swojego dotychczasowego pupila (przed listopadem 1555 r.) przejęli opiekę nad dziećmi starosty chęcińskiego pochodzącymi $z$ jego trzeciego małżeństwa. Nie wchodząc w szczegóły tego długotrwałego sporu, powiedzmy jedynie, że korzystając ze śmierci głównego opiekuna, wojewody krakowskiego Stanisława Tęczyńskiego, który zmarł 5 grudnia 1560 r., kilkanaście dni później Oleśnicki, Chełmski i Kreza dokonali zbrojnego zajęcia dóbr i zamku Piesko-

${ }^{11}$ Por. D. Quirini-Popławska, Kreza Mikołaj, [w:] PSB, t. XV, WrocławWarszawa-Kraków 1970, s. 295; A. Boniecki, Herbarz polski, t. XII, Warszawa 1908, s. 278; Z. W dowis zews ki, op. cit., s. 193; S. Starowols ki, Monumenta Sarmatarum, Cracoviae 1655, k. 781; B. Paprocki, Herby rycerstwa polskiego, wyd. K.J. Turowski, Kraków 1858, s. 368-369; K. Nies iecki, op. cit., t. V, Lipsk 1840, s. 382-383; Archiwum Główne Akt Dawnych w Warszawie [dalej: AGAD], Metryka Koronna [dalej: MK] 78, k. 21v-22; J. Pielas, Oleśniccy herbu Dębno $w$ XVI-XVII wieku. Studium z dziejów zamożnej szlachty doby nowożytnej, Kielce 2007, s. 219. 
wa Skała, które przeszły w ich wspólna posesję. W maju 1563 r. cała trójka zawarła zaś ugodę $z$ Mikołajem Secygniowskim w sprawie dóbr włoszczowskich. Obie strony umorzyły wszystkie wzajemne pretensje i procesy dotyczące tej majętności. Oznaczało to potwierdzenie prawa Chełmskich, Krezów i Oleśnickich do objęcia w posiadanie Włoszczowy oraz należących do tego klucza wiosek. Jednocześnie zięciowie Hieronima Szafrańca podjęli decyzję o przekazaniu Secygniowskiemu tenuty wolbromskiej w depozyt sekwestrowy. W 1564 r. Zofia z Szafrańców Oleśnicka zrzekła się jednak swoich praw do części Wolbromia na rzecz sędziego ziemskiego krakowskiego Mariana Przyłęckiego. Wkrótce potem to samo uczyniła Katarzyna z Szafrańców Chełmska i tenuta wolbromska przeszła w ręce Przyłęckiego. W tej sytuacji Secygniowski pozwał w 1565 r. Chełmskich, Krezów i Oleśnickich o niedotrzymanie warunków ugody zawartej w maju 1563 r. Co ciekawe, w pozwie Secygniowskiego wniesionym do akt grodu krakowskiego nieżyjąca już żona Mikołaja Krezy konsekwentnie nazywana jest Zuzanna z Pieskowej Skały $^{12}$.

W początkach 1557 r. zmarła Anna z Szafrańców Krezina. Od tej pory w procesach o spadek po Hieronimie Szafrańcu prowadzonych przez jej męża stroną stały się ich wspólne dzieci, jako spadkobiercy matki i dziadka. Dzięki temu wiadomo, że para doczekała się trzech synów: Jana, Marcina i Jakuba oraz czterech córek: Doroty, Katarzyny, Anny i Reginy. Na epitafium Mikołaja Krezy podano, że zmarł on w wieku 67 lat. Oznacza to, że jego śmierć przypadła mniej więcej na rok 1567. Prawdopodobnie jeszcze za życia Mikołaja Krezowie odprzedali Stanisławowi Szafrańcowi przypadająca na nich trzecią część zamku i dóbr Pieskowa ${ }^{13}$. Dnia

12 Por. K. Chłapowski, Realizacja reform egzekucji dóbr 1563-1665. Sprawa zastawów królewszczyzn małopolskich, Warszawa 1984, s. 67, 215; A. Biedrzycka, op. cit., s. 438 (tu również informacja, że ostatecznie wdowa po Hieronimie Szafrańcu doprowadziła do odrzucenia zarzutów dotyczących legalności jej małżeństwa, a w 1570 r. zawarto ugodę, na mocy której jej synowie otrzymali na własność wsie Ludynię, Kozłów i Częstków z klucza włoszczowskiego); J. Piela s, op. cit., s. 196-199; J. Ku rtyka, Latyfundium tęczyńskie. Dobra i właściciele (XIV-XVII wiek), Kraków 1999, s. 197; Archiwum Narodowe w Krakowie [dalej: ANK], Castriensia Cracoviensia Inscriptiones [dalej: CCI] nr 89, s. 1325-1330.

${ }_{13}$ Por. J. Pielas, op. cit., s. 197; ANK, CCI nr 89, s. 1325-1330; nr 91, s. 1126-1127; B. Pa procki, op. cit., s. 369 (tu informacja, że Mikołaj Kreza miał z Anną Szafrańcówną synów Jana, Marcina i Jakuba oraz cztery córki); S. S tar owolski, op. cit., s. 781; I. Ka niew ska, Szafraniec Stanisław z Pieskowej Skały, [w:] PSB, t. XLVI, s. 477 (tu również informacja, że przed rokiem 1567 przypada- 
16 marca 1574 r. synowie Mikołaja i Anny z Szafrańców Krezów dokonali w Krakowie podziału dóbr po rodzicach. Starszy z nich - Jan objął dobra ojcowskie, czyli zamek Bobolice $z$ folwarkiem oraz wsie Niegowa $z$ folwarkiem i prawem prezenty tamtejszego proboszcza, Mzurów z folwarkiem, Tomiszewice, Lgota, Ogorzelik i Zdów, wsie puste Bobolki, Niegówka i Sadowie oraz pozostające w zastawie wioski Dąbrówno i Zalesice. Na dział młodszego $z$ braci - Marcina przypadły natomiast dobra macierzyste, należące niegdyś do dziadka Krezów, Hieronima Szafrańca. W skład schedy Marcina Krezy wchodziły: miasto Włoszczowa $z$ wójtostwem, wieś Włoszczowa $z$ folwarkiem i prawem prezenty proboszcza w tamtejszym kościele parafialnym oraz wsie Wola Wiśniowa, Nieznanowice $z$ folwarkiem, Ząbrzec, Sułków, Ostrów, Borowe Karczmy, Czartoszowy, Jedle, Łopuszno i Mniów. Obejmując te dobra, młodszy $z$ braci Krezów wziął też na siebie obowiązek zabezpieczenia interesów materialnych pozostałego rodzeństwa - brata Jakuba i sióstr Katarzyny oraz Anny. Tej ostatniej, żony Floriana Cieklińskiego, należał się posag zabezpieczony na dobrach bobolickich. Bracia ustalili więc również, że Marcin dokona przeniesienia tej wierzytelności z Bobolic na dobra włoszczowskie. Dotrzymanie warunków przeprowadzonego wówczas działu zagwarantowano zakładem w wysokości 20000 florenów $^{14}$. Ponieważ zaś w podziale dóbr po Mikołaju i Annie Krezach dokonanym w marcu 1574 r. nie uczestniczyły już ich córki Dorota i Regina, zasadne wydaje się przypuszczenie, że obie zmarły bezpotomnie przed tą datą.

Kilka tygodni później zmarł również Jakub - najmłodszy z braci Krezów. Już 8 kwietnia 1574 r. Marcin Kreza skwitował bowiem brata Jana $z$ zapisu 500 florenów, czyli połowy sumy, która ten ostatni zapisał wcześniej zmarłemu właśnie bratu Jakubowi ${ }^{15}$. Nie wiemy nic o losach starszej z córek Mikołaja i Anny Krezów - Katarzyny. Najpewniej nie wyszła za mąż i zmarła bezpotomnie. Nieco więcej można za to powiedzieć o młodszej z Krezianek, Annie. Jak wspomniałem, w chwili podziału dóbr po rodzicach była ona żona Floriana Cieklińskiego h. Awdaniec. Fakt ten znajduje potwierdzenie również w innych przekazach źródłowych. Dnia 26 lutego

jącą na nich trzecią część dóbr i zamku Pieskowa Skała odprzedali też Szafrańcowi Remigian i Katarzyna Chełmscy).

${ }^{14}$ Por. AGAD, MK 111, k. 180-182. Dodajmy także, że występujace w przywołanym tu akcie nazwisko szwagra Krezów - Floriana Cieklińskiego zostało zapisane w mocno zniekształconej formie. Nazwano go tu bowiem Florianem Kietlińskim.

15 Por. AGAD, MK 111, k. 129v-130. 
1574 r. król Henryk Walezy wyraził zgodę na to, aby Florian Ciekliński i jego żona Anna, córka nieżyjącego Mikołaja Krezy z Bobolic, wykupili wójtostwo w mieście Częstochowa $z$ rąk dotychczasowych posiadaczy i objęli je w dożywotnie posiadanie ${ }^{16}$. Wiemy także, że małżonkowie Cieklińscy byli użytkownikami wsi królewskich Plaskowice i Turowice w powiecie opoczyńskim. Dnia 6 kwietnia 1590 r. król Zygmunt III Waza zezwolił bowiem Florianowi Cieklińskiemu i jego żonie Annie na wydzierżawienie tych wsi dowolnej osobie, a 15 czerwca 1593 r. zgodził się na to, aby Anna z Bobolic, wdowa po Florianie Cieklińskim, scedowała wsie Pląskowice i Turowice na syna Jana ${ }^{17}$. Ten ostatni jest już postacia nieco bardziej znaną. W 1608 r. był bowiem komornikiem granicznym sandomierskim, latach 1609-1612 opoczyńskim, a w 1612 r. chęcińskim. Dwukrotnie, w roku 1622 oraz w latach 1627-1628, pełnił również funkcję podstarościego i sędziego grodzkiego w grodzie nowokorczyńskim. Zmarł pod koniec 1632 lub też w początkach $1633 \mathrm{r}$. W dniu 15 lutego tego roku Władysław IV nadał bowiem wakujace po śmierci Cieklińskiego wsie królewskie Pląskowice, Turowice i Rudzisko swojemu dworzaninowi, Aleksandrowi Brzeskiemu ${ }^{18}$.

$Z$ cała pewnościa możemy zatem stwierdzić, że zmarły na przełomie 1632 i 1633 r. Jan Ciekliński był potomkiem Zygmunta Starego i Katarzyny Telniczanki. Ta sama konstatacja mogłaby się odnosić do jego dzieci i ewentualnego rodzeństwa. Problem w tym, że nie dysponujemy żadnym rzetelnym opracowaniem genealogii rodziny Cieklińskich h. Awdaniec. Wystarczy zreszta powołać się na trzy najbardziej spektakularne przykłady. Zdaniem Kaspra Niesieckiego Florian Ciekliński miał z żoną, pochodząca $z$ domu Krezów, córkę Zofię, poślubioną Adamowi Bielińskiemu, stolnikowi zakroczymskiemu, a następnie nieznanemu $z$ imienia Rusieckiemu, skarbnikowi warszawskiemu, oraz trzech synów - znanego nam już Jana, sędziego grodzkiego nowomiejskiego (nowokorczyńskiego) i komornika sandomierskiego, Stanisława, rotmistrza królewskiego, i Mikołaja. Jan, ożeniony z Sułowska, miał być ojcem tylko jednej córki, którą wydał za Józefa Kowalskiego, podkomorzego wieluńskiego. Rotmistrz Stanisław, ożeniony z Katarzyna

16 Por. AGAD, MK 112, k. 54v-55v.

17 Por. AGAD, MK 133, k. 437v, 570-571.

18 Por. J. Pielas, Urzędnicy grodzcy nowokorczyńscy i ich kariery w XVII wieku, [w:] Dzieje biurokracji, t. IV, cz. 1-2, red. A. Górak, K. Latawiec, D. Magier, LublinSiedlce 2011, s. 139, 143, 146, 149; A. Boniecki, op. cit., t. III, Warszawa 1900, s. 172; AGAD, MK 180, k. 15v. 
Śmiotanczanką, chorażanką podolska, pozostawił po sobie, zdaniem cytowanego heraldyka, tylko syna Marcina, sędziego grodzkiego kamienieckiego i latyczowskiego. Wreszcie ostatni $z$ synów Floriana Cieklińskiego - Mikołaj miał być, zgodnie $z$ ustaleniami Kaspra Niesieckiego, ojcem trzech synów - Dobiesława, kasztelana czechowskiego (jedynego senatora w rodzinie Cieklińskich), ożenionego z Katarzyną Zofią Kostczanką, córką Mikołaja Rafała Kostki, starosty malborskiego, i Zofii z Pileckich; Aleksandra, który pozostawił po sobie dwie córki - Kalińską i Miączyńską; oraz Jakuba ${ }^{19}$. W herbarzu Seweryna Uruskiego powielono w zasadzie wywody Niesieckiego, wprowadzając jedynie kilka poprawek. Wśród dzieci Floriana Cieklińskiego nie wymieniono córki Zofii. Janowi dano za żonę nie Sułowską, ale Annę Wielogłowską. Nie wspomniano też o jego domniemanej córce. Ostatnia zmianą dokonana przez autorów herbarza w genealogii tej gałęzi rodu Cieklińskich było zaś stwierdzenie, że nieznane $z$ imienia Kalińska i Miączyńska były córkami nie Aleksandra, ale jego brata, kasztelana czechowskiego Dobiesława $^{20}$. Już na pierwszy rzut oka widać jednak, że przedstawiony przez K. Niesieckiego wywód obarczony jest przynajmniej trzema istotnymi błędami. Wspomniany tu rotmistrz Stanisław nie był bowiem synem Floriana, tylko jego dalszego kuzyna, sekretarza królewskiego Piotra Cieklińskiego ${ }^{21}$, żaden Józef Kowalski nie sprawował urzędu podkomorzego wieluńskiego ${ }^{22}$, a matka Katarzyny Zofii z Kostków Cieklińskiej była nie Zofia Pilecka, a Katarzyna Plemięcka ${ }^{23}$. Dla odmiany, w herbarzu Adama Bonieckiego nie odnajdziemy najmniejszej nawet wzmianki o Florianie Cieklińskim ${ }^{24}$. Nie jest oczywiście wykluczone, że gorliwy kalwinista Mikołaj Ciekliński, żyjący jeszcze w roku 1627, ojciec kasztelana czechowskiego Dobiesława $^{25}$, a być może również Aleksandra i Jakuba, rzeczywiście był synem Floriana i Anny z Krezów Cieklińskich. Ostateczne roz-

${ }^{19}$ Por. K. Niesiecki, op. cit., t. III, Lipsk 1839, s. 112-113.

20 Por. S. Uruski, A.A. Ko siński, A. Włodarski, Rodzina. Herbarz szlachty polskiej, t. II, Warszawa 1905, s. 304-305.

${ }^{21}$ Por. A. Michałek, Ciekliński Stanisław, [w:] PSB, t. IV, Kraków 1938, s. 45.

${ }^{22}$ Por. Urzędnicy województw tęczyckiego i sieradzkiego w XVI-XVIII wieku. Spisy, oprac. E. Opaliński, H. Żerek-Kleszcz, red. A. Gąsiorowski, Kórnik 1993.

${ }^{23}$ Por. A. Boniecki, op. cit., t. III, s. 171.

${ }^{24}$ Por. ibidem, s. 171-172.

25 Por. W. Czapliń ski, Ciekliński Dobiesław, [w:] PSB, t. IV, s. 42; K. E s treicher, Bibliografia polska, t. XIV, Kraków 1896, s. 280 (tu imię ojca Dobiesława, który w opublikowanym w 1627 r. druku wyjaśniał motywy swojej konwersji na katolicyzm); A. Bo niecki, op. cit., t. III, s. 171 (tu informacja, że po śmierci pierw- 
strzygnięcie tej kwestii wymagałoby jednak jednoznacznego potwierdzenia źródłowego. Tę samą uwagę odnieść też należy do wzmianki o córce i siostrze Jana, podstarościego nowokorczyńskiego, jedynego na chwilę obecna przedstawiciela rodziny Cieklińskich, którego możemy uznać za niewatpliwego potomka króla Zygmunta I.

Interesująca postacia był bez wątpienia prawnuk Zygmunta Starego i Katarzyny Telniczanki, młodszy syn Mikołaja i Anny z Szafrańców Krezów - Marcin. Datę jego urodzenia możemy oszacować w przybliżeniu na rok $1542 / 1543^{26}$. Jak wspomniano, w marcu 1574 r. objął on w posiadanie dobra włoszczowskie. Nie jest jednak pewne, czy wsie wymienione w akcie podziałowym należały w całości do Krezów. Być może władali oni jedynie częściami niektórych wsi. Zgodnie $z$ ustaleniami Jacka Pielasa już w kwietniu 1574 r. Mikołaj Oleśnicki, jeden $z$ trzech synów Mikołaja $z$ Pińczowa (zm. 1566) i Zofii z Szafrańców (zm. 1566/1567), został bowiem odnotowany jako właściciel wsi Nieznanowice, Wola Wiśniowa, Zabrzec i Borowe Karczmy. Oleśniccy z Pińczowa nie zdołali jednak utrzymać tych dóbr w swoich rękach. Już w 1580 r. sprzedali bowiem wszystkie cztery wioski Stanisławowi Szafrańcowi z Pieskowej Skały, który konsekwentnie wykupował od spadkobierców Hieronima Szafrańca dawne rodowe posiadłości ${ }^{27}$. Sądzić wypada, że zaraz po przejęciu Włoszczowy Marcin Kreza odstąpił Oleśnickim należące do niego części wspomnianych tu wsi, otrzymując w zamian zrzeczenie się przez nich pretensji do pozostałej części klucza włoszczowskiego. Nawet po ustąpieniu z wsi wchodzących w skład majętności nieznanowickiej Marcin Kreza w dalszym ciągu był człowiekiem zamożnym. Zatrzymał bowiem w swoim ręku miasto Włoszczowę oraz wsie Włoszczowa, Sułków, Ostrów, Czartoszowy, Jedle, Łopuszno i Mniów ${ }^{28}$.

szej żony, zmarłej w 1644 r. Katarzyny Zofii Kostczanki, Dobiesław Ciekliński ożenił się z Eufrozyną Wołucka)).

${ }^{26}$ W 1567 r. Marcin wraz ze starszym bratem Janem występował w imieniu własnym oraz pozostałego rodzeństwa w sprawie dotyczącej przejęcia przez Stanisława Szafrańca dóbr Pieskowa Skała. Sądzić więc można, że miał wówczas ukończony 24 rok życia. Por. ANK, CCI nr 91, s. 1126-1127.

27 Por. J. Pielas, Oleśniccy..., s. 206-207, 210.

${ }^{28}$ Można przypuszczać, że w późniejszym okresie Marcin Kreza utracił jakasś część dóbr włoszczowskich na rzecz Stanisława Szafrańca, który konsekwentnie skupował majątki należące kiedyś do dziadka Krezy - starosty chęcińskiego Hieronima. Nie jest jednak prawda twierdzenie, że już przed 1570 r. S. Szafraniec „przejął większość klucza włoszczowskiego”. Por. I. Kaniewska, op. cit., s. 477. 
Marcin Kreza był bardzo gorliwym wyznawca kalwinizmu. Czynnie uczestniczył we wszystkich wydarzeniach związanych $z$ działaniami podejmowanymi przez polskich dysydentów. W $1580 \mathrm{r}$. odebrał katolikom kościół we Włoszczowie i zamienił go na zbór kalwiński. W tym samym roku publicznie zdeptał Eucharystię, po czym rzucił ja psom na pożarcie. Upomniał go za to Stefan Batory, ostrzegając jednocześnie, że jeśli podobne wykroczenie się powtórzy, będzie zmuszony do podjęcia bardziej zdecydowanych działań. $\mathrm{Na}$ początku lat osiemdziesiątych XVI w. Marcin Kreza ściągnął do Włoszczowy Grzegorza z Żarnowca (ok. 1528-1601), który został ministrem włoszczowskiego zboru i pozostał w tym mieście do końca życia. W 1587 r. Kreza uczestniczył w zjeździe szlachty małopolskiej pod Pokrzywnica i podpisał jego uchwały. W sierpniu 1595 r. zarówno Marcin Kreza, jak i Grzegorz wzięli udział w synodzie toruńskim. Marcin podpisał się pod uchwałami tego synodu. W lutym 1596 r. Kreza byl gospodarzem synodu dystryktowego we Włoszczowej. W maju 1599 r. uczestniczył z Grzegorzem z Żarnowca w zjeździe ewangelików i prawosławnych w Wilnie. Został tu wybrany jednym $z$ prowizorów mających sprawować opiekę nad współwyznawcami $z$ prowincji małopolskiej i zabiegać o utrzymanie pokoju religijnego. W maju 1606 r. podpisał w Krakowie protestację przeciwko złożeniu na dzień 3 czerwca tego roku sejmiku szlachty krakowskiej w Proszowicach ${ }^{29}$. Podobnie jak wielu innych jego współwyznawców wziął udział w rokoszu sandomierskim. Dnia 24 czerwca 1607 r. w obozie pod Jezierna podpisał akt wypowiedzenia posłuszeństwa Zygmuntowi III. Jeszcze 1 listopada 1608 r. wniósł do ksiagg grodzkich krakowskich zobowiązanie do spłaty 600 florenów długu wobec Andrzeja Oleśnickiego i 100 florenów wobec Piotra Gruszczyńskiego ${ }^{30}$. Jest to ostatnia

${ }^{29}$ Por. J. Łukaszewicz, O kościołach braci czeskich $w$ dawnej Wielkopolsce, Poznań 1835, s. 169; i d e m, Dzieje kościołów wyznania helweckiego w Litwie, t. I, Poznań 1842, s. 132; J. Wij a c zka, Reformacja w miastach prywatnych $w$ Koronie w XVI wieku, „Roczniki Dziejów Społecznych i Gospodarczych” 2016, t. LXXVII, s. 389; J. Tazbir, Bluźniercy, którzy uszli karze, „Nauka” 2011, nr 1, s. 8; H. Kow alska, Grzegorz z Żarnowca, [w:] PSB, t. IX, Wrocław-Warszawa-Kraków 1960-1961, s. 91-93; Volumina legum, wyd. J. Ohryzko, t. II, Petersburg 1859, s. 237; Akta sejmikowe województwa krakowskiego [dalej: ASK], t. I (1572-1620), wyd. S. Kutrzeba, Kraków 1932, s. 298.

${ }^{30}$ Por. H. Schmitt, Kilka uwag $w$ sprawie rokoszu Zebrzydowskiego, "Roczniki Towarzystwa Przyjaciół Nauk Poznańskiego", t. III, Poznań 1865, s. 62; ANK, CCI nr 187, s. 1473-1477. 
znana mi wzmianka źródłowa dotycząca Marcina Krezy. Być może zmarł wkrótce potem.

Z nieznanej żony (lub też żon) Marcin Kreza pozostawił dwóch synów - Marcina juniora oraz Piotra. Starszy z nich - Marcin, urodził się na poczatku lat osiemdziesiątych XVI stulecia. Na przełomie 1594 i 1595 r. w towarzystwie wojewodzica lubelskiego Jana Amora Tarły, Mariana Przyłęckiego i Jana Gosławskiego udał się na studia do Heidelbergu. Dnia 2 stycznia 1595 r. wpisał się do ksiag miejscowego uniwersytetu, gdzie zaznaczono, że był jeszcze „iniuratus propter aetatem”, co oznacza, że nie miał ukończonych 14 lat $^{31}$. $Z$ cała pewnością Marcina juniora dotyczy również wzmianka w instrukcji dla posłów na sejm obranych na sejmiku proszowskim 5 lutego 1613 r., gdzie w postulatach wpisano, aby „sprawa pp. Krezów o zabicie nieboszczyka p. Marcina brata ich $z$ p. Kłobukowskiem, aby na tym sejmie koniecznie sądzona była" ${ }^{32}$. Starszy z synów Marcina Krezy seniora zmarł więc przed rokiem 1613. Zapewne nie zdążył się ożenić. Jego młodszy brat - Piotr urodził się zapewne w drugiej połowie lat dziewięćdziesiątych XVI w. Adam Boniecki odnotował jego obecność na sesji trybunalskiej w Lublinie w 1619 r. ${ }^{33}$ Dnia 28 września 1621 r. Piotr Kreza uczestniczyl, $z$ bratem stryjecznym Aleksandrem, w popisie pospolitego ruszenia powiatu chęcińskiego, który odbył się pod Szydłowem ${ }^{34}$. Zmarł bezżennie i bezpotomnie zapewne przed 15 kwietnia $1624 \mathrm{r}$.

${ }^{31}$ Por. D. Żoła dź, Studenci polscy z Korony i Litwy na uniwersytecie $w$ Heidelbergu w okresie reformacji, „Rozprawy z Dziejów Oświaty” 1994, t. XXXVI, s. 13; oraz Die Metrikel der Universität Heidelberg von 1386 bis 1662, hrsg. von G. Toepke, Bd. II, Heidelberg 1886, s. 177.

32 Por. ASK, t. I, s. 347. Trzeba też w tym miejscu zaznaczyć, że wobec niemożności jednoznacznego rozróżnienia Marcina seniora i Marcina juniora Krezów, równie dobrze to młodszy $z$ nich mógł aktywnie uczestniczyć w życiu politycznym województwa krakowskiego w pierwszym dziesięcioleciu XVII w. Nie wiemy również, czy zamieszczona w dziele Waleriana Nekandy Trepki informacja, że jakiśs Kreza dzierżawił wójtostwo w Bochni od Stanisława Morskiego i jego żony Anny $z$ Cikowskich dotyczy Marcina seniora, Marcina juniora czy też raczej Aleksandra, syna Jana Krezy. Por. W. Nekanda Trepka, Liber generationis plebeanorum „Liber chamorum”, wyd. W. Dworzaczek, J. Bartyś, Z. Kuchowicz, cz. 1 (Wstępy wydawców i tekst), Wrocław-Warszawa-Kraków 1963, s. 73.

${ }^{33}$ Por. A. Boniecki, op. cit., t. XII, s. 278.

${ }^{34}$ Por. Rejestr popisu pospolitego ruszenia powiatu chęcińskiego 28 września 1621 roku, [w:] Źródła i materiały do dziejów szlachty województwa sandomierskiego w XVI-XVIII wieku, t. I (Rejestry pospolitego ruszenia szlachty sandomierskiej z XVII wieku), oprac. J. Pielas, Kielce 2009, s. 30. Dosłownie zapisano tu, że na popisie stawił „JMP Aleksander Kryza z Piotrem, synowcem swym, koni 3”. 
Nie odnotowano już bowiem jego udziału w okazowaniu szlachty chęcińskiej, które odbyło się właśnie w tym czasie ${ }^{35}$. Nie żył już $z$ pewnością 25 czerwca 1625 r., kiedy wyraźnie wspomniano o nim jako o zmarłym ${ }^{36}$.

Jan Kreza $z$ Bobolic, najstarszy syn Mikołaja i Anny Szafrańcówny, nie zapisał się niczym szczególnym w sferze publicznej. W herbarzach odnotowano jedynie, w ślad za Szymonem Starowolskim, że był ożeniony $z$ nieznaną księżniczką Sanguszkówną i miał $z$ nią syna Aleksandra. Możemy w tym miejscu dodać, że Jan Kreza, urodzony zapewne na poczatku lat czterdziestych $\mathrm{XVI} \mathrm{w.}{ }^{37}$, nie okazał się zbyt dobrym gospodarzem. Prowadząc życie ponad stan, poważnie zadłużył dobra bobolickie. Skorzystał $z$ tego sekretarz królewski, ksiądz Stanisław Fogelweder, archidiakon warszawski, kanonik krakowski, wileński i płocki ${ }^{38}$, który wykupił długi Krezy od jego wierzycieli i rozpoczał zabiegi o przejęcie zamku w Bobolicach oraz wsi wchodzacych w skład tego klucza. W dniach 26 i 27 sierpnia 1588 r. do akt Metryki Koronnej wniesiono szereg wpisów, w których wierzyciele Krezy przenieśli swoje prawa do długów zabezpieczonych na dobrach bobolickich na Fogelwedera. Uczynili tak Walerian Tęgoborski (520 złotych na wsi Tomiszowice), Jan Kuczkowski (2700 złotych na wsiach Mzurów i Niegówka), Stanisław Giebułtowski (1300 złotych na wsi Zdów), Florian Ciekliński, szwagier Krezy (400 złotych na wsi Ogorzelik) oraz Mikołaj Silnicki (2200 złotych na wsi Niegowa). Przy tej samej okazji Kreza pozbył się trzech innych długów, oddając 112 złotych Walerianowi Tęgoborskiemu, 300 złotych Janowi Kuczkowskiemu oraz 100 złotych Stanisławowi Giebułtowskiemu. W niewielkim tyko stopniu poprawiło to jednak jego sytuację. Co ciekawe, w przywołanych tu aktach występuje również żona Jana Krezy - Małgorzata Sienguszkówna (niewątpliwa księżniczka, gdyż w tej formie właśnie

Stwierdzenie, że Piotr był bratankiem Aleksandra, wynika najpewniej z tego, że obu dzieliła bardzo duża różnica wieku.

${ }^{35}$ Por. Rejestr okazowania powiatu checinskiego w 1624 roku, [w:] ibidem, s. 39-44.

36 Por. Archiwum Państwowe w Łodzi [dalej: APŁ], Archiwum Leopoldów z Rzepiszewa [dalej: ALzRz] nr 54, k. 9v.

${ }_{37}$ Już w 1566 r. Jan Kreza został odnotowany jako właściciel wsi Niegowa. W roku następnym reprezentował (wraz z bratem Marcinem) pozostałe rodzeństwo w sprawie dotyczącej objęcia przez Stanisława Szafrańca części dóbr Pieskowa Skała. Por. ANK, CCI nr 91, s. 505-506, 1126-1127.

${ }^{38}$ Więcej na jego temat por. Ł. Ku rdy ba cha, Fogelweder Stanisław, [w:] PSB, t. VII, Kraków 1948-1958, s. 44-46. 
zapisywano często nazwisko Sanguszków), która wyrażała wcześniej zgodę na obciążanie przez męża dóbr bobolickich kolejnymi długami ${ }^{39}$. Dnia 26 marca 1589 r. swoje prawa do długów zabezpieczonych na zamku Bobolice oraz innych dobrach Jana Krezy przeniósł też na Fogelwedera kasztelan sandomierski Stanisław Tarnowski ${ }^{40}$. Wkrótce potem Stanisław Fogelweder objął w posiadanie cały klucz bobolicki. Kiedy bowiem 15 kwietnia tego roku Zygmunt III wystawił Fogelwederom akt potwierdzajacy szlachectwo Stanisława i jego bratanków, Andrzeja, Josta i Stanisława, archidiakon warszawski został już nazwany Stanisławem Fogelwederem $z$ Bobolic ${ }^{41}$. W poczatkach 1589 r. zatem Krezowie utracili zamek w Bobolicach i nigdy już do niego nie powrócili. Warto więc może przy tej okazji sprostować funkcjonujaca powszechnie, a bałamutna informację, jakoby zamek w Bobolicach pozostawał w rękach Krezów aż do wygaśnięcia tego rodu w 1625 r. O dalszych losach Jana Krezy niewiele więcej wiadomo. W herbarzach odnotowano jedynie, że pozostawił po sobie syna Aleksandra i córkę Urszulę ${ }^{42}$. Zmarł przed rokiem $1600^{43}$.

Głównym źródłem informacji o życiu Aleksandra Krezy z Bobolic jest inskrypcja na jego pomniku nagrobnym. Dowiadujemy się z niej, że jego matka była księżniczka Sanguszkówna, czyli znana nam już Małgorzata. Informacja ta była czasami podawana w wątpliwość, gdyż księżniczka o tym imieniu nie pojawia się w żadnej genealogii rodu Sanguszków. W cytowanej inskrypcji widnieje zapis, że Aleksander Kreza rozpoczął swoją służbę wojskowa, walczac pod rozkazami Stefana Batorego przeciwko Moskwie ${ }^{44}$. Jeśli tak było $\mathrm{w}$ istocie, to należy założyć, że ok. 1580 r. Kreza musiał mieć przynajmniej 15-16 lat. Urodziłby się zatem nie później niż w roku 1565. Małżeństwo jego rodziców musiało zatem

39 Por. AGAD, MK 135, k. 240-251v.

40 Por. ibidem, k. 442v-443v.

${ }^{41}$ Por. AGAD, MK 133, k. 352v-355. W dniu 30 VII 1593 r. Stanisław Fogelweder, dziedzic Bobolic, wniósł do Metryki Koronnej akt darowizny wsi Mzurów na rzecz bratanka Jodoka oraz zamku w Bobolicach $z$ reszta klucza bobolickiego na rzecz innego bratanka, Stanisława. Por. AGAD, MK 138, k. 299v-301.

${ }^{42}$ Por. K. Niesiecki, op. cit., t. V, s. 383; A. Boniecki, op. cit., t. XII, s. $278-279$.

${ }^{43}$ W 1600 r. Aleksander Kreza, syn zmarłego Jana, wniósł do grodu sieradzkiego akt przeniesienia prawa do sumy 3000 florenów zapisanej mu przed aktami grodu krakowskiego przez Andrzeja Szafrańca na Mikołaja Maja, syna zmarłego Jana. Por. AGAD, Sieradzkie grodzkie, inskrypcje [dalej: SGI] 103, k. 173.

${ }^{44}$ Por. S. Starowols ki, op. cit., s. 790-791. 
zostać zawarte krótko przed tą datą. To zaś każe nam poszukiwać księżniczki Sanguszkówny urodzonej około 1545 r. Co prawda, na pierwszy rzut oka trudno znaleźć wśród ówczesnych Sanguszków parę małżeńska, która mogłaby mieć córkę urodzoną w tym czasie, ale być może dalsze poszukiwania źródłowe pomoga rozwiązać i tę zagadkę. Spadkobiercy Aleksandra Krezy zadbali o umieszczenie na jego epitafium informacji, że brał on udział w bitwie pod Byczyną oraz w tłumieniu powstania Semena Nalewajki. Służył też pod rozkazami Jana Zamoyskiego w wyprawie na Mołdawię w 1595 r. oraz przeciwko Michałowi Walecznemu w 1600 r. Walczył też w Inflantach oraz na kresach przeciwko Turkom i Tatarom ${ }^{45}$. Ostatnie lata życia spędził we Włoszczowie, której po śmierci brata stryjecznego Piotra był chyba rzeczywiście jedynym dziedzicem. Podczas okazowania szlachty powiatu chęcińskiego w kwietniu 1624 r. jego poczet został odnotowany wśród pocztów przysłanych przez wdowy, sieroty, a także chorych i starych ${ }^{46}$. Zmarł 19 kwietnia 1625 r. bezżennie, jako ostatni męski potomek rodu Krezów ${ }^{47}$. Podobnie jak ojciec Jan, stryj Marcin i dziadek Mikołaj, do końca życia był wyznawca kalwinizmu.

Urszula Krezianka była córka Jana i siostra Aleksandra. Jak się jednak wydaje, nie była dzieckiem księżniczki Małgorzaty Sanguszkówny. Urszula wyszła bowiem za mąż za Krzysztofa Strasza $z$ Białaczowa h. Odrową̇. $Z$ inskrypcji nagrobnej tego ostatniego wynika zaś, że urodził się on około 1594 r. ${ }^{48} \mathrm{Na}$ tej podstawie możemy wnioskować, że Strasz poślubił Urszulę najwcześniej w 1618 r. Nie wydaje się możliwe, żeby w chwili zamążpójścia panna miała więcej niż 25-28 lat. Urodziła się zatem najwcześniej na początku lat dziewięćdziesiątych XVI w., a być może nawet nieco później. Była więc przynajmniej o 25 lat młodsza od Aleksandra, co każe nam uznać ją za jego siostrę przyrodnią. Po śmierci starszego brata objęła w posiadanie miasto Włoszczowę $z$ niewielkimi przyległościami (w tym czasie klucz włoszczowski z pewnością był znaczaco mniejszy w porównaniu ze stanem $z$ początku rząów Marcina Krezy). Mąż Urszuli, gorliwej kalwinistki, Krzysztof z Białaczowa Strasz był katolikiem. Tytułował się sekretarzem królew-

45 Por. ibidem, s. 791.

46 Por. Rejestr okazowania..., s. 43.

47 Por. S. Starowolski, op. cit., s. 791.

48 Por. K. Niesiecki, op. cit., t. V, s. 383; A. Boniecki, op. cit., t. XII, s. 278-279; S. Starowolski, op. cit., s. 790. 
skim (po raz pierwszy $z$ tym tytułem wystapił w lutym 1636 r.). Walczył z Moskwą i Turkami pod rozkazami Jana Karola Chodkiewicza. Wziął też udział w wojnie ze Szwecją o ujście Wisły toczonej w latach 1626-1629. Urszula $z$ Krezów Straszowa, gorliwa kalwinistka, zmarła zapewne w 1628 r. W roku następnym Krzysztof Strasz ożenił się bowiem z Zofią Oleśnicką h. Dębno, córką Jana i Izabeli $z$ Chyckich. W latach trzydziestych XVII w. Krzysztof i Zofia Straszowie zlikwidowali zbór we Włoszczowie i oddali katolikom odebraną im wcześniej świątynię. Druga żona Strasza zmarła w 1636 r. Sam zaś Krzysztof umarł w roku 1644, przeżywszy 50 lat ${ }^{49}$.

$Z$ małżeństwa $z$ Urszulą Krezianką Krzysztof Strasz pozostawił dwoje dzieci - syna Władysława, dworzanina pokojowego królewicza Karola Ferdynanda Wazy i kolejnego dziedzica Włoszczowy ${ }^{50}$, oraz córkę Krystynę. Ta ostatnia została wydana za Wawrzyńca Załuskiego h. Junosza. Krystyna ze Straszów Załuska żyła jeszcze w czerwcu 1655 r., kiedy przeniosła na brata prawo do sumy 4000 złotych, jakie winien jej był Stanisław Koryciński, kasztelan biecki ${ }^{51}$. Władysław Strasz z Białaczowa 26 stycznia 1658 r. roborował $\mathrm{w}$ grodzie krakowskim umowę zawartą $z$ Mikołajem Chrzanowskim ${ }^{52}$. Około roku 1660 sprzedał Włoszczowę Jakubowi z Lubrańca Dąmbskiemu h. Godziemba, chorążemu zatorskiemu i oświęcimskiemu. Jak się wydaje, zmarł bezżennie. Nic nie wiadomo również o potomstwie jego siostry, Krystyny Załuskiej. Aż do chwili obecnej panowało przekonanie, że Władysław i Krystyna z Białaczowa Straszowie byli ostatnimi polskimi potomkami Zygmunta Starego i Katarzyny Telniczanki. Nie jest to jednak prawda.

Dzięki długim poszukiwaniom udało mi się bowiem odnaleźć dokument, który rzuca nowe światło na genealogię rodu Krezów ${ }^{53}$.

${ }^{49}$ Por. K. Niesiecki, op. cit., t. VIII, s. 555; S. Starowolski, op. cit., s. 790; J. Pielas, Oleśniccy..., s. 317-318; J. Wijaczka, op. cit., s. 389; Rejestr okazowania powiatu chęcińskiego w 1636 roku, [w:] Źródła i materiały do dziejów..., t. I, s. 46.

${ }^{50}$ Por. K. Niesiecki, op. cit., t. VIII, s. 555; S. Starowolski, op. cit., s. 790.

51 Akt ten niewatpliwie istnieje, bo informacja o jego treści pojawia się na portalach internetowych. W księgach grodzkich krakowskich nie udało mi się go niestety odnaleźć.

52 Por. ANK, CCI 278, s. 396-397 (umowę tę zawarto w Maluszynie 19 I 1658 r.).

53 Już kilka lat temu w księgach grodzkich łęczyckich natknąłem się na informację, że żoną Baltazara Lutomirskiego była Zofia Krezianka. W żadnym ze znanych mi wpisów nie podano jednak imienia jej ojca. Nie wspomniano również o tym, że pochodziła ona $z$ rodziny piszacej się „z Bobolic”. Wyjaśnienie tej kwestii wymagało zatem podjęcia poszukiwań w innych zespołach archiwalnych. 
W pierwszej kolejności zwróćmy jednak uwagę na sformułowanie zawarte $\mathrm{w}$ inskrypcji umieszczonej na pomniku nagrobnym Aleksandra Krezy. Pojawia się tu zwrot fratrem sororibus - bratem siostrom $^{54}$. Nie fratrem sorori, ale właśnie sororibus. Oznaczać to może tylko jedno - Aleksander Kreza miał oprócz Urszuli Straszowej jeszcze jedną siostrę. I to taką, która żyła dłużej od niego i zadbała o to, aby takie właśnie sformułowanie znalazło się na pomniku. Siostra ta była Zofia z Bobolic Krezianka, żona Baltazara (Jana Baltazara, Baltazara Jana) Lutomirskiego h. Jastrzębiec. Potwierdza to jednoznacznie dokument oblatowany przez męża Zofii w grodzie piotrkowskim 28 czerwca 1625 r. Tego dnia Lutomirski zapisał żonie sumę 31000 złotych, która zabezpieczył na wszystkich swoich dobrach. Przy okazji podał, jakie zobowiązania składały się na tę kwotę. Było to 4000 florenów posagu i wiana Zofii, 4000 florenów zapisanych jej tytułem długu w grodzie chęcińskim, 6000 florenów stanowiących jej część spadku po Piotrze Krezie oraz, co najważniejsze - 17000 florenów przypadających na nia tytułem naturalnej sukcesji (succesionis naturalis) po Aleksandrze Krezie $z$ Bobolic ${ }^{55}$. To ostatnie sformułowanie rozstrzyga $\mathrm{w}$ istocie $\mathrm{w}$ sposób definitywny cała sprawę. Skoro Urszula z Krezów Straszowa nie objęła całości schedy po Aleksandrze, to oznaczać to mogło tylko jedno - drugą osobą uprawnioną do udziału w spadku była jego i jej siostra. Wspomniana tu kwota 17000 florenów stanowiła zaś bez wątpienia spłatę, którą Lutomirscy przyjęli od Straszów $\mathrm{w}$ zamian za rezygnację na ich rzecz $z$ prawa do połowy majętności włoszczowskiej ${ }^{56}$.

Zofia Krezianka z Bobolic była bez wattpienia młodszą córką Jana Krezy, rodzoną siostrą Urszuli i przyrodnia siostrą Aleksandra. Urodziła się w połowie lat dziewięćdziesiątych XVI w., a być może nawet kilka lat później. Jak już wiadomo, za Lutomirskiego wyszła przed rokiem 1625. Zmarła w pierwszej połowie 1636 r. ${ }^{57}$

${ }^{54}$ Por. S. Starowolski, op. cit., s. 791.

55 Por. APŁ, ALzRz nr 54, k. 9-9v.

56 Dnia 20 I 1626 r. Baltazar Lutomirski rozliczył się ostatecznie z Krzysztofem Straszem. Otrzymał bowiem wówczas ostatnia ratę należności za rezygnację z połowy dóbr włoszczowskich. Dokonując stosownych wpisów do ksiąg grodzkich krakowskich, Lutomirski skwitował Strasza $z$ sumy 3500 florenów i - w pełni już zaspokojony - scedował na niego prawa do wierzytelności na kwotę 7000 florenów. W tym samym dniu Baltazar Lutomirski udzielił też pożyczki w wysokości 1500 florenów innemu Straszowi - Janowi. Por. ANK, CCI 224, s. 28-31.

${ }^{57}$ Por. AGAD, Łęczyckie grodzkie, inskrypcje [dalej: ŁGI] 169, k. 332v-335. 
Mąż Zofii - Baltazar Lutomirski był trzecim synem i szóstym, najmłodszym dzieckiem Baltazara Lutomirskiego (zm. 1587), starosty sieradzkiego i leżajskiego, oraz Beaty Elżbiety z Tarnowskich h. Leliwa, wojewodzianki sandomierskiej. Urodził się zapewne około $1575 / 1578$ r. ${ }^{58}$ Wraz ze starszymi braćmi - Mikołajem i Stanisławem był właścicielem miasta Lutomierska i kilku przyległych wsi w powiecie szadkowskim województwa sieradzkiego. Podobnie jak jego rodzice oraz bracia był wyznawca kalwinizmu. Pod koniec lat dwudziestych XVII w. kupił od Anny z Dalikowa Sarnowskiej, żony Jana Koniecpolskiego, późniejszego wojewody sieradzkiego, wieś Krępę w powiecie szadkowskim. We wrześniu $1631 \mathrm{r}$. wydzierżawił ja na trzy lata Pawłowi Malskiemu. W kolejnych zaś latach procesował się z Koniecpolskimi o niedotrzymanie warunków sprzedaży Krępy ${ }^{59}$. Po bezpotomnej śmierci najstarszego brata Mikołaja przeją połowę jego udziałów w dobrach lutomierskich. W kwietniu 1627 r. wraz z bratem Stanisławem zastawił Lutomiersk z przyległościami za 18000 florenów wdowie po Mikołaju - Mariannie z Gorajskich, wówczas już żonie Stanisława Plichty, pisarza ziemskiego sochaczewskiego ${ }^{60}$. Wkrótce po wykupieniu dóbr lutomierskich $z$ tego zastawu, 8 lipca 1630 r. bracia Lutomirscy zastawili je za kwotę 20000 florenów kasztelanowi łęczyckiemu Adamowi Walewskiemu. Dwa lata później zastaw zamieniono na dzierżawe i pozostawiono Lutomiersk przyległościami w rękach Walewskiego

58 Dnia 5 II 1588 r. Beata $z$ Tarnowa, wdowa po Baltazarze Lutomirskim, staroście sieradzkim i leżajskim, skwitowała Andrzeja Opalińskiego z sumy 10000 florenów zabezpieczonych przez jej zmarłego męża na tenucie leżajskiej. Występowała wówczas jako opiekunka małoletnich synów - Mikołaja, Stanisława i Baltazara Jana. Por. AGAD, MK 134, s. 103-105. Najstarsza córka Baltazara Lutomirskiego i Beaty Tarnowskiej, Beata, już w 1592 r. była żoną łożniczego królewskiego i starosty bobrujskiego Jana Bojanowskiego. Por. AGAD, MK 137, k. 220v-221. Po jego śmierci wyszła za mąż za Jana z Chomięży Balińskiego, kasztelana bydgoskiego, a owdowiawszy po raz drugi, poślubiła w 1605 r. Adaukta, czyli Zbożnego Smerzyńskiego, wojewodzica inowrocławskiego. W 1609 r. owdowiała po raz trzeci. Nie żyła już w 1612 r. Por. Biblioteka Kórnicka PAN [dalej: BK PAN], Teki Dworzaczka [dalej: TD], Monografie, Lutomierscy, Lutomirscy h. Jastrzębiec. Druga starościanka sieradzka - Zofia wyszła w 1593 r. za Jana z Mirowa Myszkowskiego, z czasem wojskiego oświęcimskiego. W chwili zamążpójścia tej siostry Jan Baltazar był jeszcze małoletni. Por. ANK, CCI 148, s. 191-195, 205-208. Trzecia z sióstr Lutomirskich - Anna, została żona Stanisława z Romiszewic Stokowskiego. Por. APŁ, ALzRz nr 54, k. 5.

59 Por. APŁ, ALzRz nr 30, k. 2-10.

${ }^{60}$ Por. APŁ, ALzRz nr 54, k. 11-12 (akt roborowany w grodzie w Szadku 20 IV 1627 r.). 
na okres do 30 maja 1633 r. ${ }^{61}$ Latem 1636 r. Baltazar Lutomirski sprzedał swoja połowę Lutomierska $z$ połowa wsi Czołczyn, Zolew i Wrzaca wojewodzie rawskiemu Andrzejowi Grudzińskiemu ${ }^{62}$, który druga połowę dóbr lutomierskich nabył w tym samym czasie od synów zmarłego Stanisława - Adama i Mikołaja ${ }^{63}$. Kiedy w lipcu tego roku Baltazar Lutomirski roborował spisana w Poddębicach umowę sprzedaży Lutomierska w grodzie łęczyckim, jego żona została wspomniana jako zmarła ${ }^{64}$. Sam Lutomirski zmarł w grudniu 1638 lub też w pierwszych dniach stycznia 1639 r. ${ }^{65}$

Baltazar i Zofia $z$ Krezów Lutomirscy pozostawili po sobie syna Joachima oraz córki Annę i Zofię. W chwili śmierci ojca wszystkie dzieci były jeszcze niepełnoletnie. $Z$ opieki nad nimi zrezygnowali ich bracia stryjeczni - Adam i Mikołaj Lutomirscy, ustanawiając jednocześnie opiekuna w osobie Zygmunta Zapolskiego, stolnika sieradzkiego ${ }^{66}$. Władysław IV nie uznał jednak tej decyzji i na opiekuna młodych Lutomirskich wyznaczył Jerzego Bełdowskiego. Ten ostatni, działajac w imieniu małoletnich dzieci Baltazara Lutomirskiego - Joachima, Anny i Zofii, wystapił do sądu grodzkiego sieradzkiego przeciwko nabywcy dóbr lutomierskich, Andrzejowi Grudzińskiemu o sumę 30000 florenów oprawy nieżyjącej już ich matki Zofii Krezianki zabezpieczonej na Lutomiersku i przyległych wsiach. W roku 1639 sąd grodzki zasądził sporna sumę Lutomirskim. Grudziński miał im wypłacić po 10000 florenów - Joachimowi po osiagnięciu pełnoletności, a jego siostrom po zamęściu ${ }^{67}$.

Jedyny syn Baltazara i Zofii Lutomirskich - Joachim, dziedzic na Krępie, zmarł młodo i bez wątpienia bezżennie. Już w 1648 r. wspomniano o nim jako o nieżyjącym ${ }^{68}$. Starsza $z$ córek - Anna, jak można przypuszczać, zmarła jako panna. Jej młodsza siostra - Zofia, urodzona około 1630 r., już 25 czerwca 1650 r. była żoną

${ }^{61}$ Por. AGAD, SGI, 137, k. 199-200v, 314v; SGI, 139, k. 567-569. Por. też M. Kobi e r ecki, Walewscy herbu Kolumna w XVII-XVIII wieku. Genealogia. Majętności. Działalność publiczna, Łódź 2008, s. 28.

62 Por. AGAD, LGI, 169, k. 332v-335.

${ }^{63}$ Akt rezygnacji $z$ dóbr lutomierskich na rzecz Grudzińskiego za sumę 31000 florenów roborował Mikołaj Lutomirski w grodzie sieradzkim 28 VII 1636 r. Por. APE, ALzRz nr 13, k. 54.

${ }^{64}$ Por. AGAD, ŁGI, 169, k. 332

${ }^{65} \mathrm{~W}$ akcie wniesionym do grodu sieradzkiego w styczniu 1639 r. wspomniano o Baltazarze Lutomirskim jako o „właśnie zmarłym”. Por. AGAD, SGI, 149, k. 190v.

66 Por. ibidem.

${ }^{67}$ Por. AGAD, ŁGI, 175, k. 446-447.

68 Por. APE, ALzRz nr 30, k. 11. 
Stanisława Trembińskiego (Trębińskiego) h. Rogala, syna Feliksa ${ }^{69}$. Miała $z$ nim córki Teresę i Zuzannę, odnotowane w źródłach w lutym 1661 r. $^{70}$ Po śmierci pierwszego męża Zofia Lutomirska poślubiła Franciszka Szamowskiego h. Prus I, syna Stanisława i Heleny z Pieczkowskich (Pięczkowskich) h. Jelita ${ }^{71}$. Dożywocie spisała $z$ nim 10 kwietnia 1659 r. ${ }^{72}$ Franciszek Szamowski bardzo aktywnie uczestniczył w życiu publicznym, uczestnicząc w sejmikach łęczyckich i posłując ze swojego województwa na sejmy. Na sejmie zwyczajnym w roku 1672, wraz z innymi posłami łęczyckimi, wywołał gniew króla Michała, nazywając jego ubiór „błazeńskim”. Dnia 9 maja 1684 r. otrzymał nominację na urząd stolnika łęczyckiego. Po śmierci Jana III posłował na sejm elekcyjny i uczestniczył w elekcji Fryderyka Augusta Wettyna ${ }^{73}$. Zofia $z$ Lutomirskich Szamowska zmarła przed 8 sierpnia $1691 \mathrm{r} .{ }^{74}$ Franciszek Szamowski ożenił się po raz drugi z Teresa ze Stempowskich (Stępowskich), wdowa po Pawle Prażmowskim. Przeżył również tę żonę. Drugie małżeństwo Szamowskiego było bezdzietne. Dnia 19 listopada 1700 r. stolnik łęczycki spisał w Witaliszewicach (Witaszewicach) testament, roborowany następnie w grodzie łęczyckim. Zmarł wkrótce potem. $Z$ małżeństwa $z$ Zofią $z$ Lutomirskich Franciszek Szamowski pozostawił troje dzieci: synów Jana i Jakuba oraz córkę Konstancję ${ }^{75}$.

Spośród córek Stanisława Trembińskiego (Trębińskiego) i Zofii Lutomirskiej o Teresie nic więcej nie wiadomo. Najpewniej zmarła młodo jako panna. Druga córka tej pary - Zuzanna Trembińska (Trębińska) została natomiast w lutym 1670 r. wydana za mąż za Ludwika z Wyszyny Grodzieckiego h. Dryja, syna Adama, kasztelana międzyrzeckiego. Otrzymała od matki i ojczyma posag w wysokości 36000 złotych $^{76}$. Jej mąż zmarł krótko po ślubie,

${ }^{69}$ Por. AGAD, Sieradzkie grodzkie, relacyjne 28a, k. 512v.

70 Por. AGAD, ŁGI, 220, k. 20-24v.

${ }^{71}$ Por. AGAD, ŁGI, 175, k. 339-341. Helena z Pieczkowskich Szamowska była córka Macieja i Anny z Tarnowskich h. Rola. Por. też M. Kobierecki, op. cit., s. 93 (tu żona Szamowskiego nazwana Heleną Piechowska).

${ }^{72}$ Por. AGAD, ŁGI, 215, k. 57-57v. W tym miejscu pragnę serdecznie podziękować Pani dr Hance Żerek-Kleszcz za nieoceniona pomoc w opracowaniu genealogii Szamowskich i udostępnienie mi własnych wypisów źródłowych do dziejów tej rodziny.

${ }^{73}$ Por. L.A. W i e rzbicki, Szamowski Franciszek, [w:] PSB, t. XLVI, s. 588-589.

${ }^{74} \mathrm{~W}$ akcie wniesionym tego dnia do grodu łęczyckiego wspomniano o niej jako o zmarłej. Por. AGAD, ŁGI, 285, k. 232-232v.

${ }^{75}$ Por. AGAD, Łęczyckie grodzkie, relacje 177, k. 224-224v; L.A. Wierzbicki, op. cit., s. 588.

${ }^{76}$ Por. BK PAN, TD, Grodzkie i ziemskie [dalej: GiZ], Konin, 10018 (Nr. 60), 1670. 
a małżeństwo było bezdzietne. Drugim mężem Zuzanny został już w 1671 r. Adam Lubstowski h. Leszczyc (zm. 21 IV 1701), stolnik inowrocławski, syn Mikołaja, starosty kruszwickiego, i Zofii Kołudzkiej77. Pod koniec życia osiagną on senatorska godność kasztelana kowalskiego ${ }^{78}$. Zuzanna $z$ Trembińskich (Trębińskich) Lubstowska zmarła po 1681, a przed 1685 r., kiedy to jej mąz ożenił się po raz drugi $z$ Izabelą Eufrozyną Mielęcką, wdową po Władysławie $z$ Łabiszyna Latalskim. Adam i Zuzanna Lubstowscy mieli pięcioro dzieci: synów Andrzeja i Macieja oraz córki Mariannę Dorotę, Zofię i Izabelę. Ta ostatnia została norbertanką w Strzelnie. Zmarła przed 1727 r. ${ }^{79}$ Najstarsza córka kasztelana kowalskiego Adama Lubstowskiego i Zuzanny z Trembińskich (Trębińskich) - Marianna Dorota wyszła w 1697 r. za mąż za Antoniego Przecława Rupniowskiego h. Szreniawa, używającego tytułu cześnika owruckiego $^{80}$. Owdowiała przed 1715 r., kiedy to jej drugim mężem był już Antoni Leszczyński. Oboje żyli jeszcze w 1734 r. ${ }^{81} \mathrm{Z}$ Rupniowskim miała syna Konstantego Wiktora, odnotowanego w aktach grodu kaliskiego w 1763 r. ${ }^{82}$ Tenże Konstanty Wiktor Rupniowski, ożeniony $z$ Marianną Doruchowską, miał z nią syna Jana Nepomucena, który w 1791 r. (za życia obojga rodziców) ożenił się z Wiktorią Kozłowską, córką Jakuba i Józefy Gołeckiej, wdową po Jakubie Myszkowskim $^{83}$. Z Antonim Leszczyńskim Marianna Dorota z Lubstowskich miała syna Józefa, ożenionego później z Rozalią Lubiatowską. Józef Leszczyński zmarł bezpotomnie przed $1742 \mathrm{r}^{84}$

Druga $z$ córek kasztelana kowalskiego Adama i Zuzanny z Trembińskich (Trębińskich), Zofia Lubstowska w 1701 r. poślubiła Jana Pawła Szygowskiego h. Trzaska, starostę kruszwickiego. Owdowiała po nim przed 1716 r. Wkrótce potem została żoną Jana Antoniego Tarchalskiego. W roku 1720 była zaś już po raz trzeci zamężna za Franciszkiem Maciejem Jarnowskim h. Topór, łowczym brzesko-

77 Jeszcze przed ślubem oprawił on Zuzannie na swoich dobrach 9000 złotych posagu i tyleż wiana. Por. ibidem, Konin, 10043, (Nr. 60), 1671.

78 Por. Urzędnicy kujawscy i dobrzyńscy XVI-XVIII wieku. Spisy, oprac. K. Mikulski, W. Stanek, przy udziale Z. Górskiego, R. Kabacińskiego, red. A. Gąsiorowski, Kórnik 1990, s. 123.

79 Por. BK PAN, TD, Monografie, Lubstowscy h. Leszczyc.

80 Por. BK PAN, TD, GiZ, Konin, 11668, (Nr. 70), 1697.

81 Por. BK PAN, TD, Monografie, Leszczyńscy różni.

82 Por. BK PAN, TD, GiZ, Kalisz, Inskrypcje, XVII/XVIII wiek, 6456 (Nr. 204/205), 1763.

${ }^{83}$ Por. BK PAN, TD, GiZ, Kościan, Inskrypcje, 11378 (Nr. 337), 1791.

${ }^{84}$ Por. BK PAN, TD, Monografie, Leszczyńscy różni. 
kujawskim. Zmarła przed 1741 r. Ani $z$ drugim, ani $z$ trzecim mężem nie miała dzieci ${ }^{85}$. Janowi Pawłowi Szygowskiemu urodziła natomiast synów Adama, Aleksandra, Władysława, Konstantego i Stefana oraz córki Ludwikę i Katarzynę. Najstarsza córka Zofii Lubstowskiej - Ludwika Szygowska już w 1716 r. była żoną Stanisława Domaradzkiego ${ }^{86}$. Zmarła, zapewne bezpotomnie, po $1723 \mathrm{r}$. Władysław i Stefan Szygowscy zmarli chyba przed 1719 r., gdyż nie pojawiają się już od tej pory w źródłach, w których występują wspólnie Aleksander, Konstanty, Ludwika i Katarzyna. Adama Szygowskiego odnotowano po 1716 r. tylko raz, w zapisce $z$ roku 1736. Można przypuszczać, że jeśli nie była to pomyłka pisarza dokonującego wpisu do akt grodzkich, to wkrótce potem zmarł on bezżennie i bezpotomnie ${ }^{87}$. Katarzyna w 1735 r. poślubiła Antoniego Raczyńskiego h. Nałęcz. Miała $z$ nim trzech synów - Ignacego, jezuitę, Jana, kanonika poznańskiego, i Wojciecha, kapitana wojsk koronnych. Antoni i Katarzyna z Szygowskich Raczyńscy zmarli przed 1770 r. ${ }^{88}$ Konstanty Szygowski, syn Jana Pawła, starosty kruszwickiego, i Zofii z Lubstowskich ożenił się z Zofią Borkówną Gostyńska h. Gryzima, córką Adama i Doroty z Werbna Rydzyńskiej. Zmarł przed $1770 \mathrm{r}$. Nie pozostawił po sobie potomstwa ${ }^{89}$. Ostatni ze starościców kruszwickich, Aleksander Szygowski, ożeniony z Katarzyna ze Stolińskich, miał z nia troje dzieci: Józefa, Augustyna i Mariannę, od 1766 r. żonę Kazimierza Ostrowskiego. O Józefie i Mariannie nic więcej nie wiadomo. Natomiast Augustyn około 1779 r. poślubił Juliannę z Markowskich, wdowę po Wojciechu Milewskim. Oboje żyli jeszcze w 1790 r. ${ }^{90}$

85 Por. BK PAN, TD, Monografie, Lubstowscy h. Leszczyc; TD, Zap. Tryb. Piotrk. [dalej: ZTP], 540 (Nr. 41), 1723 (tu Marcin Tarchalski jako spadkobierca brata Jana Antoniego); GiZ, Poznań, Inskrypcje, XVII/XVIII wiek, 10551 (Nr. 121/I), 1727 (tu Franciszek Maciej Jarnowski jako ojciec adopcyjny dzieci swojej pierwszej żony, Krystyny Chełkowskiej, urodzonych z jej małżeństwa ze Stanisławem Golemowskim).

${ }^{86}$ Por. BK PAN, TD, GiZ, Nakło, Część 1, 6147, (Nr. 199), 1716 (tu wymienione wszystkie dzieci Jana Pawła Szygowskiego i Zofii Lubstowskiej).

87 Por. BK PAN, TD, GiZ, Kcynia, 5539 (Nr. 134), 1719; GiZ, Gniezno, Część 1, 12359 (Nr. 97), 1735; 12477 (Nr. 97), 1736.

88 Por. BK PAN, TD, GiZ, Kościan, Inskrypcje, 10683 (Nr. 331), 1770; GiZ, Poznań, Inskrypcje, XVII/XVIII wiek, 16960 (Nr. 1356), 1779; 17080 (Nr. 1357), 1780.

89 Por. BK PAN, TD, GiZ, Poznań, Inskrypcje, XVII/XVIII wiek, 6617 (Nr. 1270), 1743; GiZ, Gniezno, Część 1, 12724 (Nr. 98), 1747; GiZ, Konin, 14971 (Nr. 80), 1770.

90 Por. BK PAN, TD, GiZ, Gniezno, Część 1, 13962 (Nr. 100), 1766; 15712 (Nr. 111), 1784; GiZ, Poznań, Inskrypcje, XVII/XVIII wiek, 17834 (Nr. 1367), 1790. 
Andrzej Lubstowski, starszy syn Adama, kasztelana kowalskiego, i Zuzanny Trębińskiej, ożenił się około 1694 r. z Ewą Dzierżkówną, córką Adama i Katarzyny Boruckiej. Zmarł w 1701 r. Jego żona, która ponownie wyszła za mąż za Rafała Gomolińskiego, nie żyła już na pewno w roku 1724. Ich jedynym synem był Adam. W $1721 \mathrm{r}$. spisał on testament i zmarł bezpotomnie w tym samym roku $^{91}$. Maciej, młodszy syn kasztelana kowalskiego Adama i Zuzanny Trembińskiej (Trębińskiej), ożenił się w 1695 r. z Anną Grabską h. Wczele, córka Piotra i Zofii Sierakowskiej, bratanica zmarłych bezpotomnie Stanisława, kasztelana rogozińskiego, i Kazimierza, kasztelana śremskiego. W 1717 r. dokonał działu dóbr po ojcu ze wspomnianym bratankiem Adamem. Zmarł przed rokiem 1721. Wdowa po nim nie żyła na pewno w 1741 r. Maciej Lubstowski i Anna Grabska mieli troje dzieci: syna Andrzeja oraz córki Zofię (Ewę Zofię) i Magdalenę ${ }^{92}$. Zofia Lubstowska, starsza córka Macieja i Anny Grabskiej, w 1716 r. zaślubiła Andrzeja Komierowskiego. W 1728 r. mąż jej ustanowił opiekunów dla swojego potomstwa zrodzonego w tym małżeństwie. Wszystkie te dzieci zmarły jednak najpewniej młodo. Sam Andrzej Komierowski umarł około 1743 r. ${ }^{93}$ Drugim mężem Ewy Zofii Lubstowskiej został Michał Kalkstein-Stoliński h. Kos odm. Owdowiała po nim w 1760 r. Zmarła bezpotomnie około roku $1762^{94}$. Magdalena, młodsza córka Macieja Lubstowskiego i Anny Grabskiej, w 1724 r. została żoną Andrzeja Jarnowskiego h. Topór. Miała $z$ nim synów Andrzeja, Ignacego Bartłomieja (ur. 1733) i Wojciecha Stanisława (ur. 1740) oraz córkę Elżbietę (ur. 1735). Ignacy zmarł jako dziecko. Elżbieta wyszła za Jana Ciechanowicza. Jako wdowa po nim wystapiła w 1766 r. Synowie Andrzej i Wojciech Jarnowscy w 1773 r. objeli spadek po bezpotomnej śmierci bratanka swojej matki - Tomasza Lubstowskiego. Późniejsze ich losy nie sa mi znane. Magdalena $z$ Lubstowskich Jarnowska zmarła przed 1759 r. ${ }^{95}$

${ }^{91}$ Por. BK PAN, TD, Monografie, Lubstowscy h. Leszczyc.

92 Por. ibidem.

${ }^{93}$ Por. ibidem; oraz TD, ZTP, 6488 (Nr. 203), 1728; GiZ, Nakło, Część 1, 6933 (Nr. 209), 1743.

${ }^{94}$ Por. BK PAN, TD, Monografie, Lubstowscy h. Leszczyc; GiZ, Nakło, Część 1, 7326 (Nr. 11), 1760.

${ }^{95}$ Por. BK PAN, TD, Metrykalia, Katolickie, 15017 (Barcin), 15019 (Barcin), 15026 (Barcin); GiZ, Kcynia, 3465 (Nr. 144), 1759; 3638, (Nr. 147), 1766; Gniezno, Część 1, 14317 (Nr. 100), 1773. 
Andrzej Lubstowski, jedyny syn Macieja i Anny Grabskiej, ożenił się w 1721 r. z Małgorzatą Elżbietą Kalkreyterówną h. wł., córką Adama i Florentyny Zofii Gorzeńskiej. Owdowiał w 1741 r. Jego druga żona była Ewa Grochowicka, córka Aleksandra i Katarzyny $z$ Dorpowskich, wdowa po Jakubie Romanie. Andrzej Lubstowski zmarł w 1760 r. Jego druga żona nie żyła już na pewno w roku 1772. Zmarła bezpotomnie. Trójka dzieci Andrzeja pochodziła $z$ jego pierwszego małżeństwa. Byli to synowie Tomasz i Ludwik oraz córka Joanna Małgorzata ${ }^{96}$. Ta ostatnia została żoną Stefana Radoszewskiego h. Oksza (zm. 1780), chorążego kowalskiego. Nie żyła już w 1772 r. Przeżyła wszystkie dzieci urodzone w tym małżeństwie, więc spadek po niej przypadł w udziale bratu Tomaszowi ${ }^{97}$. Młodszy $z$ synów Andrzeja Lubstowskiego i Małgorzaty Elżbiety Kalkreyterówny - Ludwik został cystersem w klasztorze w Lązie. W 1747 r. otrzymał od ojca zapis 6000 złotych jako udział z dóbr rodzicielskich. Starszy syna Andrzeja - Tomasz, urodzony w 1724 r., zmarł bezżennie i bezpotomnie 10 lipca 1773 r. Spadek po nim przypadł w udziale synom jego ciotki Magdaleny - Wojciechowi i Andrzejowi Jarnowskim ${ }^{98}$. Tomasz był ostatnim potomkiem Zygmunta Starego i Katarzyny Telniczanki noszacym nazwisko Lubstowski.

Konstancja Szamowska, jedyna córka Franciszka i Zofii Lutomirskiej, przed 1686 r. poślubiła chorążego pomorskiego Michała Działyńskiego h. Ogończyk (zm. 20 IX 1713), syna Stanisława, wojewody malborskiego, i Marianny z Iwińskich h. Łodzia, który już po jej śmierci został kasztelanem brzeskokujawskim. W 1691 r., w pełni wyposażona, ustapiła $z$ dóbr rodzicielskich. Zmarła 8 kwietnia 1701 r. ${ }^{99} \mathrm{Z}$ małżeństwa $\mathrm{z}$ Michałem Działyńskim miała Konstancja trzy córki: Eleonorę, Joannę i Ludwikę. O rękę Eleonory zawarł jej ojciec w 1708 r. układ z Wojciechem z Wrzaccy Zajączkiem h. Swinka pod zakładem 30000 złotych ${ }^{100}$. Nie wiadomo jednak, czy doszło do jego finalizacji, gdyż Zajączek wkrótce potem umarł.

96 Por. BK PAN, TD, Monografie, Lubstowscy h. Leszczyc.

97 Por. BK PAN, TD, GiZ, Kcynia, 3778 (Nr. 148), 1772.

98 Por. BK PAN, TD, Monografie, Lubstowscy h. Leszczyc; oraz GiZ, Gniezno, Część 1, 14317 (Nr. 100), 1773.

${ }_{99}$ Por. K. Piwars ki, Działyński Michał († 1713), [w:] PSB, t. VI, Kraków 1948, s. 92; AGAD, ŁGI, 285, k. 232-232v; BK PAN, TD, Metrykalia, Katolickie, Część 3, 17946 (Niechanowo).

100 Por. BK PAN, TD, GiZ, Gniezno, Część 1, 10967 (Nr. 93), 1708. 
W tej sytuacji Eleonora Działyńska 10 marca 1710 r. wyszła za maż̇ za Jerzego Hieronima $z$ Labiszyna Latalskiego h. Prawdzic, syna Władysława i Izabeli Eufrozyny Mielęckiej. Jako wdowa po nim występowała już w $1721 \mathrm{r}$. Zmarła przed $1738 \mathrm{r}$. Jedynym synem Jerzego Hieronima Latalskiego i Eleonory $z$ Działyńskich był Władysław Latalski (drugi ich syn - Stanisław Jan, ur. w 1716 r., zmarł w dzieciństwie). Data śmierci Władysława Latalskiego nie jest znana. Żył on jeszcze w 1747 r. Jako zmarły wspomniany został dopiero w 1780 r. Zmarł bezpotomnie jako ostatni z Latalskich w Wielkopolsce ${ }^{101}$. Druga córka kasztelana brzeskokujawskiego Michała Działyńskiego i Konstancji z Szamowskich - Joanna (ur. 30 V 1700) 3 stycznia 1719 r. poślubiła w Niechanowie Michała Boksę Radoszewskiego h. Oksza, syna Stanisława i Anny Bojanowskiej. Miała $z$ nim tylko jednego syna - Jana. Zmarła przed 1739 r. ${ }^{102}$ Tenże Jan Boksa Radoszewski, syn Michała i Joanny Działyńskiej, w 1753 r. ożenił się z Katarzyna Padniewska h. Nowina, córką Antoniego i Marcjanny Żółtowskiej. Żył jeszcze w 1780 r., kiedy jego żona została wspomniana jako zmarła. Jan Boksa Radoszewski zmarł bezpotomnie przed 1793 r. ${ }^{103}$ Najmłodsza córka Michała Działyńskiego i Konstancji Szamowskiej - Ludwika w 1722 r. poślubiła Kazimierza Grabowieckiego h. Grzymała, syna Zygmunta i Doroty Skrzydlewskiej. Oboje żyli jeszcze w 1735 r. ${ }^{104}$ Nie mam żadnych wiadomości o ich dalszych losach.

Młodszy syn Franciszka Szamowskiego i Zofii z Lutomirskich - Jakub ożenił się z Katarzyną Gembicka h. Nałęcz, córką Stefana, kasztelana płockiego, i Anny Krasińskiej h. Ślepowron. Miał z nią tylko jedna córkę - Annę, która wydał za Pawła Oborskiego h. Roch II, chorażego zawkrzeńskiego. Zmarł po 1700, a przed 1730 r. ${ }^{105}$ Paweł Oborski i Anna Szamowska podobno pozostawili po sobie jakieś potomstwo. Nie dysponuję jednak żadnymi infor-

101 Por. BK PAN, TD, Monografie, Latalscy h. Prawdzic.

102 Por. BK PAN, TD, GiZ, Gniezno, Część 1, 11376 (Nr. 94), 1719; 12643 (Nr. 97), 1739; Metrykalia, Katolickie, Część 3, 17862 (Niechanowo); 17930 (Niechanowo).

103 Por. BK PAN, TD, GiZ, Poznań, Inskrypcje, XVII/XVIII wiek, 12123 (Nr. 1309), 1753; Gniezno, Część 1, 15125 (Nr. 107), 1780; 16576 (Nr. 117), 1793 (tu wyraźne stwierdzenie, że Jan Boksa Radoszewski zmarł bezpotomnie).

104 Por. BK PAN, TD, GiZ, Gniezno, Część 1, 4966 (Nr. 1186), 1722; 12345 (Nr. 97), 1735 (tu Ludwik Działyński, starosta powidzki, nazwany bratem rodzonym Ludwiki Działyńskiej. W istocie był on jednak jej bratem przyrodnim, synem Michała i jego drugiej żony, Ludwiki Niegolewskiej).

105 Por. AGAD, Łęczyckie grodzkie, oblaty [dalej: ŁGO], 4, k. 31v-34. 
macjami źródłowymi na ten temat. Starszy brat Jakuba Szamowskiego - Jan urodził się około 1660 r. W roku 1687 poślubił Teresę z Czermińskich h. Jelita, wdowę po Franciszku Piekarskim. Żona Jana była córką Jana Czermińskiego i Anny z Mirowa Myszkowskiej h. Jastrzębiec. Jan zmarł przed 1700 r., gdyż jako zmarły został wspomniany w testamencie swojego ojca ${ }^{106}$. Nie znamy natomiast nawet przybliżonej daty śmierci wdowy po nim. Jan Szamowski i Teresa Czermińska mieli dwóch synów: Antoniego i Adama. Obaj bracia jako synowie Jana i Teresy wystapili w akcie $z$ grudnia 1721 r., kiedy dokonali podziału dóbr Witaliszewice (Witaszyce) ${ }^{107}$. Młodszy z braci - Adam Szamowski ożenił się z Ewą Jerzmanowska h. Dołęga i miał z nią syna Felicjana Ignacego (ur. 1725) oraz córki Juliannę Mariannę (ur. 1732) i Annę. Pierwsza dwójka zmarła najpewniej w dzieciństwie. Anna natomiast w 1754 r. poślubiła komornika ziemskiego sieradzkiego Franciszka Wardęskiego h. Leliwa ${ }^{108}$. Nie wiadomo, czy miała $z$ nim dzieci.

Starszy $z$ synów Jana Szamowskiego i Teresy Czermińskiej - Antoni ożenił się z Justyną Morawicką h. Jelita, córką Krzysztofa, podstolego ciechanowskiego, i Zofii z Krzesimowa Karbowskiej h. Sas. Żona Antoniego urodziła się około 1692 r. W akcie jej zgonu wpisanym do ksiag parafii w Tumie w 1752 r. odnotowano bowiem, że przeżyła 60 lat. Sam Antoni, urodzony około 1690 r., zmarł najpewniej po roku $1747^{109}$. Para ta doczekała się synów Felicjana i Ignacego oraz córek Katarzyny i Anny. Starsza z córek Antoniego Szamowskiego i Justyny z Morawickich, Katarzyna, w 1740 r. wyszła za mąż za Józefa Grabowskiego. Miała $z$ nim dwie córki: Barbarę Konstancję (ur. 1741) i Cecylię (1744-1746) ${ }^{110}$. Młodsza córka Antoniego i Justyny z Morawickich Szamowskich - Anna przed 1746 r. poślubiła Piotra z Głogowy Kossowskiego h. Dołęga, łowczyca łęczyckiego. W małżeństwie tym urodziła syna Teo-

106 Por. AGAD, ŁGI, 280, k. 15v-17v; ŁGR, 177, k. 224-224v; M. Kobie recki, op. cit., s. 245 (tu informacja o Teofili z Piekarskich Grabskiej, córce Teresy Czermińskiej z jej pierwszego małżeństwa).

107 Por. AGAD, ŁGI, 329, k. 324v-325.

108 Por. Akta Stanu Cywilnego [dalej: ASC] parafii Góra św. Małgorzaty, 1725, 1732; parafii Topola Królewska, 1754, Geneteka, baza Polskiego Towarzystwa Genealogicznego [dalej: Geneteka].

109 Por. AGAD, ŁGI, 343, k. 54v-55v; ASC parafii Tum, 1752, Geneteka; M. Kobierecki, op. cit., s. 245 .

110 Por. ASC parafii Łęczyca, 1741; parafii Topola Królewska, 1740, 1746. Geneteka. 
dora Stanisława (ur. przed 1746) oraz córki - Franciszkę (ur. ok. 1746) i Helena (ur. 1747). Teodor Kossowski zmarł zapewne w młodym wieku. Jego siostra Franciszka przed 1766 r. poślubiła Wojciecha Pieńkowskiego, z którym miała synów Nikodema (ur. 1766) i Ildefonsa Franciszka (ur. 1768). Franciszka $z$ Kossowskich Pieńkowska zmarła w 1773 r. ${ }^{111} \mathrm{O}$ dalszych losach Heleny Kossowskiej nie potrafię nic więcej powiedzieć.

Starszym z synów Antoniego i Justyny z Morawickich był Felicjan Szamowski, urodzony około 1719 r., który sprawował kolejno kilka urzędów ziemskich, kończąc swoją karierę na podczaszostwie orłowskim. Urzad ten sprawował w latach 1776-1787, po czym zrezygnował $z$ niego na rzecz swojego syna Ignacego. Felicjan Szamowski ożenił się w 1746 r. z Eleonora Kwiatkowską h. Gryf (ok. 17281794), córką kasztelana inowłodzkiego Jana Jaksy Kwiatkowskiego i Marianny z Dembińskich. Felicjan i Eleonora $z$ Kwiatkowskich Szamowscy doczekali się 12 dzieci. Byli to w kolejności narodzin: Magdalena (ur. ok. 1747), Marianna (ur. ok. 1748), Florian Augustyn (ur. 1750), Brygida Wiktoria (ur. 1754), Wincenty Kazimierz (ur. 1756), Katarzyna (ur. 1757), Ignacy (ur. 1758/1759), Romuald Jan (ur. 1759/1760), Onufry (ur. 1760), Mateusz Mikołaj (ur. 1765), Justyna Franciszka (ur. 1767) i Idzi Franciszek (ok. 1772-1774). Spośród tak licznego potomstwa tej pary wieku dojrzałego dożyły dwie córki - Magdalena i Marianna oraz czterej synowie - Romuald Jan, Ignacy, Onufry i Mateusz Mikołaj ${ }^{12}$. Najstarsza z dzieci Felicjana i Eleonory Szamowskich, Magdalena, w 1774 r. wyszła za mąż za Antoniego Dzierzbickiego h. Topór (zm. ok. 1780), cześnika inowłodzkiego, a następnie podstolego orłowskiego. Miała z nim syna Wawrzyńca i córkę Urszulę. W 1790 r., 10 lat po śmierci pierwszego męża, Magdalena Szamowska poślubiła Konstantego Pilchowskiego ${ }^{113}$. Druga córka Felicjana Szamowskiego i Eleonory z Kwiatkowskich, Marianna, jako z góra 50-letnia panna, poślubiła w 1804 r. Andrzeja Kozerskiego. Zmarła w roku $1808^{114}$.

111 Por. ASC parafii Piatek, 1768, 1773; Kutno-Łakkoszyn 1766, Geneteka.

112 Por. H. Że rek-Kle szcz, Szamowski Ignacy, [w:] PSB, t. XLVI, s. 589; ASC parafii Rdutów, 1748, 1750, 1768; parafii Tum 1754, 1756, 1757, 1759, 1760, 1765, 1767, 1773, 1774, 1794 (tu podano, że Eleonora z Kwiatkowskich Szamowska zmarła w wieku 66 lat), 1803 (tu informacja, że Felicjan Szamowski przeżył 84 lata), Geneteka.

113 Por. AGAD, ŁGI, 383, k. 94-94v; H. Żerek-K1eszcz, op. cit., s. 589; ASC parafii Tur, 1790, Geneteka.

114 Por. ASC parafii Łęczyca, 1804, 1808, Geneteka. 
Najstarszy z synów Felicjana i Eleonory Szamowskich, którzy dożyli dorosłości, Ignacy pełnił przekazany mu przez ojca urząd podczaszego orłowskiego. Był przeciwnikiem Konstytucji 3 maja i jednym $z$ organizatorów konfederacji targowickiej w województwie łęczyckim. W czasach Księstwa Warszawskiego w roku 1809 został posłem na sejm, a w 1811 r. - deputowanym z okręgu łęczycko-orłowskiego. Występował też w tym czasie jako pułkownik Wojska Polskiego. Zmarł 24 października 1827 r. W 1802 r. ożenił się w Warszawie z Rozalia z Zawadzkich (zm. 23 III 1850), córką Andrzeja, dyrektora policji $w$ Łowiczu oraz Magdaleny $z$ Barszczów. Jedynym synem Ignacego i Rozalii Zawadzkiej był urodzony w poczatkach sierpnia 1802 r. Eugeniusz Kajetan Szamowski (zm. 27 II 1870)115. Kolejny $z$ synów Felicjana Szamowskiego i Eleonory z Kwiatkowskich - Romuald Jan zmarł jako kawaler w 1795 r., w wieku 35 lat ${ }^{116}$. Następny $z$ braci Szamowskich - Onufry był choraż̇ym kawalerii narodowej ${ }^{117}$. Nic więcej na jego temat nie udało się ustalić. Czwarty syn Felicjana i Eleonory z Kwiatkowskich Szamowskich - Mateusz Mikołaj był szambelanem królewskim. Około 1790 r. ożenił się z Marianna z Poleskich h. Krzywda (ur. 12 XII 1773), córką Ludwika i Wiktorii Rozdrażewskiej h. Doliwa. Zmarł 1 czerwca 1835 r., pozostawiwszy po sobie owdowiałą małżonkę i trzy córki: Magdalenę, Teresę i Felicjannęę ${ }^{118}$.

Ignacy Szamowski był młodszym synem Antoniego i Justyny Morawickiej. Urodził się na przełomie roku 1736 i 1737 (został ochrzczony 23 II 1737 r.). Dnia 5 sierpnia 1756 r. dokonal podziału majątku po rodzicach $z$ bratem Felicjanem. Ożenił się $z$ Wiktorią z Romiszewic Stokowską h. Jelita, córką Adama (ok. 1703-1783), chorążego brzezińskiego, i Marianny Magdaleny Rojkówny h. Rawicz (1711-1790). Ignacy Szamowski w latach 1780-1792 pełnił urząd skarbnika inowłodzkiego. Zrezygnował $z$ niego na rzecz swojego jedynego syna. Zmarł w Rycerzewie 4 października 1803 r. ${ }^{119}$ $Z$ małżeństwa $z$ Wiktorią Stokowska Ignacy Szamowski miał córki

115 Por. H. Że rek-Kleszcz, op. cit., s. 589; ASC parafii Łowicz Kolegiata, 1802; parafii Tum, 1802, Geneteka.

116 Por. ASC parafii Tum, 1795, Geneteka.

117 Por. H. Żerek-Kleszcz, op. cit., s. 589.

118 Por. ibidem, s. 589; BK PAN, TD, Metrykalia, Katolickie, Część 3, 19560 (Słupy); ASC parafii Rdutów, 1835, Geneteka.

119 Por. H. Że rek-Kles zcz, Stokowski Jan Sariusz, [w:] PSB, t. XLIV, Warszawa-Kraków 2006-2007, s. 47; Urzędnicy województw..., s. 47; AGAD, ŁGO, 108, k. 269; 145, k. 97-100v; ASC parafii Tum, 1737; parafii Rdutów, 1803, Geneteka. 
Mechtyldę Rozalię (ur. 1763), urodzone w 1765 r. bliźniaczki Esterę Elżbietę i Małgorzatę Magdalenę ${ }^{120}$, oraz syna Antoniego. Bliźniaczki zmarły w dzieciństwie. Wieku dojrzałego dożyła natomiast dwójka pozostałych dzieci. Mechtylda Rozalia Szamowska (używała tylko drugiego imienia), córka Ignacego i Wiktorii ze Stokowskich, około 1790 r. wyszła za mąż za Tomasza Byszewskiego h. Jastrzębiec (1759-1840), regenta ziemskiego łęczyckiego, posła na Sejm Czteroletni. Urodziła mu trzy córki: Martę (ur. 1791), Zofię Joannę (ur. 1793) i Franciszkę Teklę (tylko ona przeżyła rodziców) ${ }^{121}$. Antoni Szamowski, jedyny syn Ignacego i Wiktorii Stokowskiej, od roku 1792, po rezygnacji ojca, pełnił urzad skarbnika inowłodzkiego. Około 1791 r. poślubił Teklę Ludwikę Poleską h. Krzywda (ur. 1772), córkę Ludwika i Wiktorii z Rozdrażewskich h. Doliwa, rodzona siostrę Marianny, żony jego brata stryjecznego, Mateusza Szamowskiego. Antoni i Tekla Szamowscy mieli 12 dzieci: Jakuba Pantaleona (ur. 1792), Wita Modesta (ur. 1794), Dionizego Felicjana (ur. 1795), Katarzynę (ur. 1797), Karolinę Luizę (1802-1804), Grzegorza Józefa (ur. 1804) oraz Elżbietę, Dominika, Alojzego, Napoleona i Ludwika Augusta. Ich dzieckiem był też zapewne Andrzej, zmarły w Tymienicy (wsi należącej w owym czasie do Antoniego) w 1794 r. ${ }^{122}$ Antoni Szamowski zmarł przed 1 grudnia 1813 r., a jego żona umarła w Rycerzewie 7 lipca 1822 r. Po śmierci Antoniego ustanowiono Radę Opiekuńcza, która miała zadbać o interesy materialne jego nieletnich dzieci. Ze sporządzonych wówczas dokumentów wiadomo, że ojca przeżyło siedmioro dzieci - córki Elżbieta i Katarzyna oraz synowie Jakub, Dominik, Alojzy, Napoleon i Ludwik August. Również w akcie zgonu Tekli $z$ Poleskich Szamowskiej wspomniano, że pozostawiła ona po sobie dwie córki i pięciu synów ${ }^{123}$.

$\mathrm{Na}$ tym wypada zamknąc nasze rozważania, gdyż dzieci Antoniego, podobnie jak potomstwo jego braci stryjecznych $z$ linii Felicjana, były już osobami czynnymi w wieku XIX, co wykracza poza ramy chronologiczne tego opracowania. Warto też na zakończenie dokonać małego podsumowania. Zwraca uwagę to, że wszyscy

\footnotetext{
${ }^{120}$ Por. ASC parafii Rdutów, 1763, 1765, Geneteka.

121 Por. AGAD, ŁGI, 396, k. 245; ASC parafii Rdutów, 1791, 1793, 1840, Geneteka.

${ }^{122}$ Por. Urzędnicy województw..., s. 48; APŁ, Sąd pokoju powiatu łęczyckiego [dalej: SPPŁ], 5, s. 2 n., 89-153; BK PAN, TD, Metrykalia, Katolickie, Część 3, 19559 (Słupy); ASC parafii Góra św. Małgorzaty, 1794, 1795; parafii Rdutów, 1797, 1804. ${ }^{123}$ Por. APŁ, SPPŁ, 5, passim; ASC parafii Rdutów, 1822, Geneteka.
} 
urodzeni na przełomie XVIII i XIX w. potomkowie Zygmunta Starego i Katarzyny Telniczanki wywodzili się od wnuczki króla - Anny z Szafrańców Kreziny, jej syna Jana Krezy, wnuczki Zofii z Krezów Lutomirskiej oraz prawnuczki Zofii $z$ Lutomirskich $1^{\circ} \mathrm{v}$. Trembińskiej (Trębińskiej) $2^{\circ}$ v. Szamowskiej. Wśród 114 zidentyfikowanych potomków przedostatniego Jagiellona na polskim tronie było 58 mężczyzn i 56 kobiet urodzonych w przedziale czasowym zawartym między poczattkiem XVI a przełomem XVIII i XIX w. (w wyliczeniu tym nie uwzględniono dzieci Zygmunta Starego i Katarzyny Telniczanki). Warto jednak zaznaczyć, że co najmniej 23 osoby z tej grupy (13 chłopców i 10 dziewczynek) zmarły w dzieciństwie lub we wczesnej młodości. Na podkreślenie zasługuje też konstatacja, że aż do końca pierwszej ćwierci XVII w. wszyscy potomkowie starszej $z$ nieślubnych córek Zygmunta Starego byli wyznawcami kalwinizmu. Dodajmy także, że wśród znanych mi descendentów króla dominowali przedstawiciele zamożnej i średniej szlachty. Nie ma natomiast nikogo, kogo można by określić mianem możnowładcy czy magnata. Żaden $z$ królewskich potomków nie zasiadł też nigdy w senacie (chyba że znajdzie się dowód na to, że kasztelan czechowski Dobiesław Ciekliński rzeczywiście był wnukiem Floriana i Anny Krezianki), a tylko nieliczni piastowali urzędy ziemskie. Jedynie dwie panny $z$ omawianej tu zbiorowości zostały żonami przyszłych senatorów (Zuzanna Trembińska (Trębińska) Adama Lubstowskiego, Konstancja Szamowska Michała Działyńskiego), z tym jednak, że ich mężowie weszli do senatu już po ich śmierci. Tylko dwaj mężczyźni poślubili natomiast córki senatorskie - Jakub Szamowski Katarzynę Gembicka, a Felicjan Szamowski Eleonorę Kwiatkowska. Niewielka grupę wśród descendentów Zygmunta I stanowili też potomkowie tzw. rodów wielkosenatorskich (troje dzieci Baltazara Lutomirskiego, trzy córki Michała Działyńskiego i jeden przedstawiciel rodziny Latalskich). Zaznaczmy jednak, że były to rodziny (może $z$ wyłączeniem Działyńskich), które utraciły już w omawianym okresie (Lutomirscy w XVII, a Latalscy w XVIII w.) swoje fortuny i wpływy polityczne. Istotna wydaje się również obserwacja, że pochodzenie od nieślubnej córki przedostatniego Jagiellona na polskim tronie ani w niczym nie zaszkodziło, ani też w niczym nie pomogło jej descendentom. Sądzić zresztą można, że w kolejnych pokoleniach zatarła się pamięć o tym, że jednym $z$ przodków Zofii $z$ Lutomirskich $1^{\circ}$ v. Trembińskiej (Trębińskiej) $2^{\circ}$ v. Szamowskiej był Zygmunt I, król polski i wielki książę litewski. Dodajmy wresz- 
cie na zakończenie, że sporządzona na potrzeby tego opracowania lista polskich potomków Zygmunta Starego i Katarzyny Telniczanki nie jest bynajmniej zamknięta. Przed kolejnymi badaczami otwierają się jeszcze (wskazane przeze mnie) pola, których wypełnienie może prowadzić do jej znaczącego uzupełnienia. Nie bez znaczenia wydaje się też obserwacja, że wśród współcześnie żyjących Polaków sa bez wątpienia potomkowie starszej $z$ nieślubnych córek Zygmunta I. Nie wydaje się jednak, żeby była to zbiorowość jakoś specjalnie liczna. Descendentów króla i Katarzyny Telniczanki jest dziś z pewnością wielokrotnie mniej niż potomków księcia raciborskiego Wacława II.

\section{Bibliografia}

\section{ŹRódea ARChIWALNe}

Archiwum Główne Akt Dawnych w Warszawie [AGAD]

Metryka Koronna [MK] 78, 111, 112, 133, 134, 135, 137, 138, 180.

Łęczyckie grodzkie, inskrypcje [ŁGI] 169, 175, 215, 220, 280, 285, 329, 343, 383, 396.

Łęczyckie grodzkie, oblaty [ŁGO] 4, 108.

Łęczyckie grodzkie, relacje 177.

Sieradzkie grodzkie, inskrypcje [SGI] 103, 137, 139, 149.

Sieradzkie grodzkie, relacyjne 28a.

Archiwum Narodowe w Krakowie [ANK]

Castriensia Cracoviensia Inscriptiones [CCI] nr 89, 91, 148, 187, 224, 278.

Archiwum Państwowe w Łodzi [APŁ]

Archiwum Leopoldów z Rzepiszewa [ALzRz] nr 13, 30, 54.

Sąd pokoju powiatu łęczyckiego [SPPŁ] 5.

Biblioteka Kórnicka PAN [BK PAN], Teki Dworzaczka [TD].

\section{Ż́ódea DRUKOWANE}

Akta sejmikowe województwa krakowskiego, t. I (1572-1620), wyd. S. Kutrzeba, Kraków 1932.

Die Metrikel der Universität Heidelberg von 1386 bis 1662, hrsg. von G. Toepke, Bd. II, Heidelberg 1886.

Paprocki B., Herby rycerstwa polskiego, wyd. K.J. Turowski, Kraków 1858.

Starowolski S., Monumenta Sarmatarum, Cracoviae 1655. 
Trepka Nekanda W., Liber generationis plebeanorum „Liber chamorum”, wyd. W. Dworzaczek, J. Bartyś, Z. Kuchowicz, cz. 1 (Wstępy wydawców i tekst), WrocławWarszawa-Kraków 1963.

Volumina legum, wyd. J. Ohryzko, t. II, Petersburg 1859.

Źródła i materiały do dziejów szlachty województwa sandomierskiego w XVIXVIII wieku, t. I (Rejestry pospolitego ruszenia szlachty sandomierskiej z XVII wieku), oprac. J. Pielas, Kielce 2009.

\section{Opracowania}

Biblioteka Kórnicka PAN [BK PAN], Teki Dworzaczka [TD], Monografie.

Biedrzycka A., Szafraniec Hieronim (Jarosz) z Pieskowej Skały, [w:] Polski słownik biograficzny, t. XLVI, Warszawa-Kraków 2009-2010, s. 436-439.

Boniecki A., Herbarz polski, t. III, Warszawa 1900; t. XII, Warszawa 1908.

Borkowska U., Dynastia Jagiellonów w Polsce, Warszawa 2011.

Burmeister K.H., Graf Georg III. von Montfort-Bregenz-Pfannberg (ca. 1475/80 1544). Eine biographische Skizze, „Monfort. Vierteljährensschrift für Geschichte, Heimat - und Volkskunde (Gegenwart) Vorarlbergs” 2009, Bd. LXI, s. 7-27.

Burmeister K.H., Montfort, von (Grafen von Montfort), [w:] Neue Deutsche Biographie, Bd. XVIII, Berlin 1997, s. 51-54.

Chłapowski K., Realizacja reform egzekucji dóbr 1563-1665. Sprawa zastawów królewszczyzn małopolskich, Warszawa 1984.

Czapliński W., Ciekliński Dobiesław, [w:] Polski słownik biograficzny, t. IV, Kraków 1938, s. 42.

Estreicher K., Bibliografia polska, t. XIV, Kraków 1896.

Kaniewska I., Szafraniec Stanisław z Pieskowej Skały, [w] Polski słownik biograficzny, t. XLVI, Warszawa-Kraków 2009-2010, s. 471-479.

Kempa T., Dzieje rodu Ostrogskich, Torun 2003.

Kobierecki M., Walewscy herbu Kolumna w XVII-XVIII wieku. Genealogia. Majętności. Działalność publiczna, Łódź 2008.

Kowalska H., Grzegorz z Żarnowca, [w:] Polski słownik biograficzny, t. IX, Wrocław-Warszawa-Kraków 1960-1961, s. 91-93.

Kurdybacha Ł., Fogelweder Stanisław, [w:] Polski słownik biograficzny, t. VII, Kraków 1948-1958, s. 44-46.

Kurtyka J., Latyfundium tęczyńskie. Dobra i właściciele (XIV-XVII wiek), Kraków 1999.

Łukaszewicz J., Dzieje kościołów wyznania helweckiego w Litwie, t. I, Poznań 1842.

Łukaszewicz J., O kościołach braci czeskich w dawnej Wielkopolsce, Poznań 1835.

Michałek A., Ciekliński Stanisław, [w:] Polski słownik biograficzny, t. IV, Kraków 1938, s. 45.

Niesiecki K., Herbarz polski, wyd. J.N. Bobrowicz, t. III, Lipsk 1839; t. V, Lipsk 1840; t. VIII, Lipsk 1841.

Pielas J., Oleśniccy herbu Dębno w XVI-XVII wieku. Studium z dziejów zamożnej szlachty doby nowożytnej, Kielce 2007. 
Pielas J., Urzędnicy grodzcy nowokorczyńscy i ich kariery w XVII wieku, [w:] Dzieje biurokracji, t. IV, cz. 1-2, red. A. Górak, K. Latawiec, D. Magier, Lublin-Siedlce 2011 , s. $137-152$.

Piwarski K., Działyński Michał († 1713), [w:] Polski słownik biograficzny, t. VI, Kraków 1948, s. 92.

Prinke R.T., Sikorski A., Polscy potomkowie Piastów i innych dynastii panujących, Poznań 1997.

Quirini-Popławska D., Kreza Mikołaj, [w:] Polski słownik biograficzny, t. XV, Wrocław-Warszawa-Kraków 1970, s. 295.

Schmitt H., Kilka uwag w sprawie rokoszu Zebrzydowskiego, „Roczniki Towarzystwa Przyjaciół Nauk Poznańskiego”, t. III, Poznań 1865, s. 1-86.

Swieżawski A., Jan (Janusz) z Książą Litewskich, [w:] Polski słownik biograficzny, t. X, Wrocław-Warszawa-Kraków 1962-1964, s. 439-441.

Swieżawski A., Kościelecka (z Kościelca) Katarzyna, [w:] Polski słownik biograficzny, t. XIV, Wrocław-Warszawa-Kraków 1968-1969, s. 397-398.

Swieżawski A., Kościelecki (z Kościelca) Andrzej, [w:] Polski słownik biograficzny, t. XIV, Wrocław-Warszawa-Kraków 1968-1969, s. 398-400.

Szczotka S., Chełmski Remigian, [w:] Polski słownik biograficzny, t. III, Kraków 1937, s. 286.

Szybkowski S., Zwiazki rodzinne Danaborskich z elita urzędnicza Kujaw i ziemi dobrzyńskiej, „Roczniki Historyczne” 2000, R. LXIV, s. 157-168.

Tazbir J., Bluźniercy, którzy uszli karze, „Nauka” 2011, nr 1, s. 7-16.

Urban W., Umiejętność pisania w Małopolsce $w$ drugiej połowie XVI wieku, „Przegląd Historyczny" 1977, t. LXVIII, z. 2, s. 231-257.

Uruski S., Kosiński A.A., Włodarski A., Rodzina. Herbarz szlachty polskiej, t. II, Warszawa 1905.

Urzędnicy kujawscy i dobrzyńscy XVI-XVIII wieku. Spisy, oprac. K. Mikulski, W. Stanek, przy udziale Z. Górskiego, R. Kabacińskiego, red. A. Gąsiorowski, Kórnik 1990.

Urzędnicy województw łęczyckiego i sieradzkiego w XVI-XVIII wieku. Spisy, oprac. E. Opaliński, H. Żerek-Kleszcz, red. A. Gassiorowski, Kórnik 1993.

Vanotti J.N., Geschichte der Grafen von Montfort und von Werdenberg, Belle-Vue, bei Constanz 1845.

Wdowiszewski Z., Genealogia Jagiellonów i Domu Wazów w Polsce, Kraków 2005.

Wierzbicki L.A., Szamowski Franciszek, [w:] Polski słownik biograficzny, t. XLVI, Warszawa-Kraków 2009-2010, s. 588-589.

Wijaczka J., Reformacja w miastach prywatnych $w$ Koronie $w$ XVI wieku, „Roczniki Dziejów Społecznych i Gospodarczych” 2016, t. LXXVII, s. 379-406.

Żelewski R., Górkowa Elżbieta (Halszka z Ostroga), [w:] Polski słownik biograficzny, t. VIII, Wrocław-Warszawa-Kraków 1959-1960, s. 424-426.

Żelewski R., Katarzyna (ok. 1503-1548), żona Jerzego II hr. Montfortu, [w:] Polski słownik biograficzny, t. XII, Wrocław-Warszawa-Kraków 1966-1967, s. 222.

Żelewski R., Łaska 1. v. Ostrogska z Kościeleckich Beata, [w:] Polski słownik biograficzny, t. XVIII, Wrocław-Warszawa-Kraków 1973, s. 222-224. 
Żelewski R., Łaski Olbracht, [w:] Polski słownik biograficzny, t. XVIII, WrocławWarszawa-Kraków 1973, s. 246-250.

Żelewski R., Ostrogski Ilia (Eliasz), [w:] Polski słownik biograficzny, t. XXIV, Wroclaw 1979, s. 480-481.

Żerek-Kleszcz H., Stokowski Jan Sariusz, [w:] Polski słownik biograficzny, t. XLIV, Warszawa-Kraków 2006-2007, s. 47-50.

Żerek-Kleszcz H., Szamowski Ignacy, [w:] Polski słownik biograficzny, t. XLVI, Warszawa-Kraków 2009-2010, s. 589-590.

Żołądź D., Studenci polscy z Korony i Litwy na uniwersytecie $w$ Heidelbergu w okresie reformacji, „Rozprawy z Dziejów Oświaty” 1994, t. XXXVI, s. 3-17.

\section{NetOGRAFiA}

Geneteka, baza Polskiego Towarzystwa Genealogicznego [Geneteka].

ZBigniew AnUsiK

\section{The royal blood. Polish descendants of Sigismund I the Old and Katarzyna Telniczanka in the old Polish times}

$\mathrm{T}$ he research undertaken by the Author concentrates on Polish descendants of Regina, the elder of two daughters of King Sigismund I the Old and his long time mistress - Katarzyna Telniczanka. Until now, it was assumed that the last descendants of the king were his great-grandsons - Władysław Strasz of Białaczów and his sister Krystyna who lived in the first half of the $17^{\text {th }}$ century. Thanks to the documents found by the Author, it was possible to establish that the mother of the above-mentioned Władysław and Krystyna - Urszula Strasz née Kreza, had a sister - Zofia, who married Baltazar Lutomirski. From her daughter, Zofia née Lutomirski $1^{\text {st }}$ married Stanisław Trembiński (Trębiński), $2^{\text {nd }}$ married Franciszek Szamowski, come all descendants of Sigismund I the Old and Katarzyna Telniczanka, both historical and living ones. The article presents a list of all the king's descendants from the beginning of the $16^{\text {th }}$ to the turn of the $18^{\text {th }}$ and $19^{\text {th }}$ century. In total, it was 114 people (58 men and 56 women). It is worth noting that until the end of the first quarter of the $17^{\text {th }}$ century, the descendants of Sigismund I and Katarzyna Telniczanka were Calvinists. They were almost exclusively representatives of wealthy and middle-class nobles. There were no senators among them and only a few were land officers. Yet, the Author's list of descendants of the penultimate Jagiellon on the Polish throne is by no means complete. In a few cases it was impossible to find a source that would confirm whether a married couple mentioned in the article had children. Many times the Author had to underline that the fate of a certain person is unknown to him. This is a chance for further researchers to fill that gap.

Keywords: Sigismund I the Old, Katarzyna Telniczanka, genealogy, descendants of Sigismund I the Old's illegitimate daughters in $16^{\text {th }}-18^{\text {th }}$ century. 